\title{
eGovernance Frameworks for Successful Citizen Use of Online Services: A Danish-J apanese Comparative Analysis
}

\author{
Morten Meyerhoff Nielsen
}

\author{
Akadeemia tee 3, Tallinn 12618, Estonia, morten. niel sen@ttu.ee \\ Rua de Vila Flor 166, 4810-445 Guimarães, Portugal, meyerhoff@unu.edu
}

\begin{abstract}
Information Communication Technology (ICT) by the public sector is often highlighted as a key tool for the transformation of public sector service delivery. Recent literature reviews have highlighted the limited understanding of the role played by governance, inter-governmental decision making and cooperation when introducing ICT solutions and online services to citizens. As part of a larger qualitative, multi-country comparison, this article compares the Danish and Japanese approaches to electronic governance (eGovernance) and inter-governmental cooperation to answer the question: Does a strong governance model and high level of intergovernmental action lead to the successful supply and use of online citizen services? The analysis finds that the two cases support academic arguments in favour of a strong eGovernance model and a high level of inter-governmental cooperation and decision making. The article finds that a political- or public sector-driven and motivated public sector modernisation, a consensus seeking and an inter-governmental approach to eGovernment, trust between actors, and the role of formal and informal are important determinants for success, as illustrated by the continued strength of the Danish governance and joint-governmental cooperation model over the more fragmented Japanese approach. Still, both countries would benefit from a more holistic approach to service delivery, process, and organisational reengineering in order to progress further.
\end{abstract}

Keywords: Digitization, eGovernment, eGovernance, Innovation, Japan, Denmark

Acknowledgement: This paper is a result of the project "SmartEGOV: Harnessing EGOV for Smart Governance (Foundations, methods, Tools) / NORTE-01-0145-FEDER-000037", supported by Norte Portugal Regional Operational Programme (NORTE 2020), under the PORTUGAL 2020 Partnership Agreement, through the European Regional Development Fund (EFDR). It was also supported by funding from Tallinn University of Technology, Project B42 and OGI - Open Government Intelligence project in the EU Horizon 2020 framework program, grant agreement 693849. 


\section{Introduction}

This article attempts to answer one key question: Does a strong governance model and high level of intergovernmental action lead to the successful supply and use of online citizen services?

As part of a larger research project, the article makes use of a comparative, qualitative, multicountry framework (2012, Yin 2013), and presents the initial findings from research carried out in Denmark and Japan.

The article is structured in eight specific sections: firstly, an introduction (section 1) and research background (section 2) is presented. Afterwards, the outline of the methodology used, the rational for the case selection, and the key socio-economic contexts for Denmark and Japan (section 3) are shown, together with the identification of the paths pursued in relation to ICT use in public administration in Denmark and Japan (section 4). This is linked with their respective approaches to governance and intergovernmental cooperation (section 5). An identification of the outcomes of the national approaches is also provided, with the article using the degree of internet availability, existence of key enablers, eServices and their use as effect indicators (section 6). Finally, the article concludes with a comparative analysis (section 7) and the association of the findings to the original research questions (section 8 ).

\section{Research Background}

The use of Information Communication Technology (ICT) and electronic government (eGovernment) strategies generally aims to increase the efficiency and effectiveness of public sector service delivery, or modernizing or even transforming public administration and society at large. The strategies developed for the introduction of information communication technology (ICT) to public administration differ between countries. Similarly, the governance and intragovernmental corporation models applied also vary, with some authorities and countries being relatively more successful in their eGovernment endeavours than others.

Despite the maturing of the eGovernment research area, limited research has been conducted on the role played by national governance models and the level of intergovernmental cooperation for the roll-out and use of online citizen services. International benchmarks have long received attention from authors like Millard and Fehlmann (2007) and international organisations like the European Commission (EC) $(2012,2014)$ or the United Nations (UN) $(2008,2010,2012,2014,2016$, 2016). Where academic or policy focused, case studies have generally examined the introduction of ICT in public administration (PA), as illustrated by Leitner et. al. (2003), Millard and Fehlmann (2007), Huijboom (2009) or the $\operatorname{OECD}(2011,2014,2015)$. Authors such as Brown and Magill (1994), Heeks (2005, 2007), Bannister and Connolly (2011), Pollitt and Bouckaert (2011), Cordella and Bonina (2012) have researched governance and cooperation but largely in relation to ICT-enabled public sector reform in the PA literature. In information systems (IS) management research by (Brown and Magill (1994), Brown and Grant (2005), Weill et al. (2006), Iribarren et. al. (2008), Klischewski and Scholl (2008), Poeppelbuss et. al. (2011) have covered governance and cooperation. While in the field of eGovernment and eGovernance the governance and cooperation 
ankles have been covered by e.g. Heeks and Bailur (2007), Millard et. al. (2008), Huijboom et. al. $(2009,2010)$.

Past research has been criticizing the public sector for only addressing specific issues. This includes blindly digitising existing processes (Bannister 2001, Traunmüller and Wimmer 2003, de Bri and Bannister 2010), shining light on technological details, or merely introducing IT and technology (Janssen, Charalabidis et al. 2012, Lips 2012, Meyerhoff Nielsen 2015). Only Andersen and Henriksen (2006), Bannister (2007), Cordella and Bonina (2012), have focused on the actual output, outcome, and impact of ICT use in public administration and for service delivery. The author's literature review $(2016,2017)$ finds that research on public sector reform, IT governance, and eGovernment does not adequately address the role which governance and cooperation plays in the successful supply and use of online eServices. While many benchmarks and case studies refer to the so-called eGovernment stage or maturity models, Meyerhoff Nielsen's analysis of 42 identified stage models and their specific meta characteristics identifies six weaknesses $(2014,2015$, 2016, 2017).

First, all models, with the exception of the Andersen and Henriksen's PPR (2006) and Klievink and Janssen's (2009) models, are technology- and supply-oriented, and do not address use or outcomes (Lee 2010, Alhomod and Shafi 2012). As tangible benefit realization of any ICT solution and eServices can only be achieved through their actual use, this is unfortunate (Meyerhoff and Kelly 2011, Meyerhoff Nielsen 2011, UNDESA - United Nations Department of Economic and Social Affairs 2014, de Bri and Bannister 2015).

Second, most models have no real understanding of core public service delivery concepts. For instance, individual service elements (e.g., information, transaction capability, and personal data) are not at separate maturity levels but are elements in a given service request and the subsequent delivery of said service. Similarly, downloadable forms are merely a type of static information and do not warrant a separate maturity level (Meyerhoff Nielsen 2015, 2017). This finding is particularly surprising, given that roughly half (i.e., 22 of 42) of the models are partially based on observations, experiences, and case studies in at least one country.

Third, back-office integration and front-office service delivery is mixed up in many models. For instance, one-stop shop portals do not constitute a form of transaction, however, it is a sign of the degree to which authorities cooperate and strive for an integrated and whole-of-government approach to service delivery via portals (Meyerhoff Nielsen 2015, 2016, 2017). Heeks (2015) partially addresses this problem with a two-dimensional matrix model which distinguishes between the back- and front-office, yet the model does not account for governance or actual use.

Forth, decision making, as exemplified by the eParticipation and eDemocracy stages, should not be considered an eGovernment maturity level. Dias and Gomes (2014) make this argument indirectly in defining engagement, petition, and voting solutions as types of public services - that is, those consisting of information, transaction capability, some form of data (e.g., election data), Internet voting solutions allowing for vote casting, and data such as unique ID numbers, names, and addresses for authorising votes. Therefore, eParticipation and eDemocracy stage(s) should be 
seen as indications of democratic maturity and transparency, not as eGovernment maturity levels (Dias and Gomes 2014, Meyerhoff Nielsen 2014, 2017).

Fifth, none of the identified models addresses governance directly. Most models indirectly address cooperation in the form of vertical and horizontal integration, the existence of one-stop shops, and information sharing among authorities and governmental levels, even private and third-party stakeholders (Chen 2011, Lee and Kwak 2012). Others, such as the Waseda index, highlight management and coordination issues, including the existence of chief information officers (Obi 2012, 2014, 2015, 2016).

Sixth, most models merely adjust or restructure existing ones. Key exceptions are Andersen and Hendriksen's PPR (2006) and Waseda's models (Obi 2012, 2014, 2015, 2016). Both build on previous models, but seek to address outcomes and governance issues.

In conclusion, past research does not address the key question asked in the introduction to this article. That is: Does a strong governance model and high level of intergovernmental cooperation lead to the successful supply and use of online citizen services? Three working hypotheses are proposed:

Hypothesis 1: A strong governance model leads to (i) supply and (ii) use of online services.

Hypothesis 2: A high level of intergovernmental cooperation leads to (i) supply and (ii) use of online services.

Hypothesis 3: A strong coordinated link between national vision, strategy, action plan, and initiatives leads to (i) supply (ii) and use of online services.

\section{Methodology}

To address the research question (Does a strong governance model and high level of intergovernmental cooperation lead to the successful supply and use of online citizen services?), as identified by Meyerhoff Nielsen's literature review and analysis of maturity (2016, 2017), a classical exploratory, qualitative, two-case comparative study methodology is applied (Benbasat, Goldstein et al. 1987, Rohlfing 2012, Yin 2013). This approach establishes a framework for in-case analysis and cross-case comparison. The aim of the in-case analysis is to identify the governance mechanisms in play in each of the two cases and a subsequent cross-case comparison. The aim of the cross-case comparison is to determine whether a correlation (i.e., the more of $Y$, the more $X$ ) exists between a strong cooperative governance model (cause) and the introduction of online services (effect 1) and subsequent citizen use of the online service delivery channel (effect 2).

To facilitate the cross-case comparison, a context, content, process model (CCP model) (Devos, Buelens et al. 2007), as adapted by Krimmer (2012), is used within each case. Developed for the use of electronic and internet-based electoral and voting technologies, Krimmer's CCP model consists of four macro-dimensions: background indicators; national governance and cooperation models; national approaches to eGovernment, and; effect measurements and preconditions. Each dimension explains a key area that influences processes, choices and outcomes in relation to eService supply and take-up. Using the framework, the article compares Denmark and Japan to 
identify their respective strengths and weaknesses in relation to their respective governance models and eGovernment experiences, with a particularly focus on the period since 2010.

\subsection{Case Selection}

Denmark and Japan are chosen based on a "most similar" but "most different" principle (Benbasat, Goldstein et al. 1987, Collier and Mahoney 1996, Yin 2013). In terms of population, both countries can be considered nation states with a single dominating ethnic group, language, and culture. The population is ageing in both countries, although faster in Japan, which also has a higher life expectancy and median age. Both countries have well educated, and highly urbanized populations, with population density in Japan being more than 2.5 times higher than in Denmark. School-life expectancy in Denmark is a full 19 years compared to Japan's 15 years, however, both countries have practically eradicated illiteracy and have a highly educated and skilled labour force, as illustrated in Table 1.

Socio-economically, the two countries are both high-income nation states with export driven economies. Denmark is a relatively small country by territory, population, and GDP, with an openexport lead economy with low GDP and productivity growth. Japan is, by comparison, a large country in the midst of a decade long recession. Both countries have low levels of unemployment and low unemployment rates. Japan has, by international standards, a relatively large current account deficit and one of the world's highest public debt rations, whereas the Danish public debt is relatively low for a high-income country, as outlined in Table 1.

Table 1: Socio-economic data 2016 (CIA - Central Intelligence Agency 2017)

\begin{tabular}{|c|c|c|}
\hline & Denmark & Japan \\
\hline Territorial size & $43,094 \mathrm{~km} 2$ & $377,915 \mathrm{~km} 2$ \\
\hline Population & $5,724,456$ & $126,702,133$ \\
\hline Population density & 129.5 per $\mathrm{km} 2$ & 335.8 per km2 \\
\hline Population growth & $0.22 \%\left(\right.$ est' $\left.^{\prime} 16\right)$ & $-0.19 \%\left(\right.$ est $\left.^{\prime} 16\right)$ \\
\hline Official languages & Danish & Japanese \\
\hline Ethnic composition & $\begin{array}{l}\text { Scandinavian, Inuit, Faroese, } \\
\text { Turkish, Polish, Syrian, German, } \\
\text { Iraqi. } \\
\text { Note: no percentages given. }\end{array}$ & $\begin{array}{l}\text { Japanese } 98.5 \% \text {, Koreans } 0.5 \% \text {, } \\
\text { Chinese } 0.4 \% \text {, other } 0.6 \% \text {. } \\
\text { Note: some } 230,000 \text { Japanese are of } \\
\text { Brazilian decent. }\end{array}$ \\
\hline $\begin{array}{l}\text { Live expectancy/ } \\
\text { median age }\end{array}$ & 79.4 years / 42 years & 85 years / 46.9 years \\
\hline Urbanization & 87.7\% (est'15) & 93.5\% (est'15) \\
\hline
\end{tabular}




\begin{tabular}{|c|c|c|}
\hline $\begin{array}{l}\text { School life expectancy } \\
\text { (primary to tertiary } \\
\text { education): }\end{array}$ & 19 years & 15 years \\
\hline GDP (billion) (PPP) & $€ 259.41$ bill (est'16) & $€ 4,179.84\left(\right.$ est' $\left.^{\prime} 16\right)$ \\
\hline GDP per capita (PPP) & $€ 39,492\left(\right.$ est' $\left.^{\prime} 16\right)$ & $€ 32,968$ (est'16) \\
\hline GDP growth & $1.3 \%\left(\right.$ est' $\left.^{\prime} 16\right)$ & $0.5 \%\left(\right.$ est' $\left.^{\prime} 16\right)$ \\
\hline Unemployment & $4.2 \%\left(\right.$ est' $\left.^{\prime} 16\right)$ & $3.2 \%\left(\right.$ est $\left.^{\prime} 16\right)$ \\
\hline Imports (billion) & $€ 79.85$ (est'16) & $€ 543.58$ (est'16) \\
\hline Exports (billion) & $€ 72.04$ (est'16) & $€ 533.75$ (est'16) \\
\hline Public debt & $34.2 \%$ of GDP $\left(\right.$ est' $\left.^{\prime} 16\right)$ & $237.7 \%$ of GDP (est' 16$)$ \\
\hline Current account & $-2.5 \%$ of GDP $\left(\right.$ est' $\left.^{\prime} 16\right)$ & $-5 \%$ of GDP (est'16) \\
\hline Inflation & $0.3 \%\left(\right.$ est' $\left.^{\prime} 16\right)$ & $-0.1 \%\left(\right.$ est' $\left.^{\prime} 16\right)$ \\
\hline
\end{tabular}

The two countries have similar levels of socio-economic development and infrastructural sophistication, but different history, culture, population sizes, and different organizational, cultural, and linguistic traditions. In short, Denmark and Japan offer vastly different perspectives, experiences, population size, administrative systems, and levels of complexity. In particular, the difference in administrative traditions and cultures will help isolate the potential role played by their respective governance models, the level of intergovernmental cooperation, and the strategic focus between 2010 and 2017. The aim is neither to identify difference in cultural or administrative traditions nor how they may influence decisions, but rather to identify how governance and intergovernmental cooperation models function despite these differences.

\subsection{Research Approach}

This article, and the two case studies it is based on, was developed in two steps. First, desk research was carried out and resulted in a conference paper published at the peer-reviewed IFIP EGOV-ePart conference in September 2016 (Meyerhoff Nielsen 2016) and CeDEM Asia Conference in December 2016 (Meyerhoff Nielsen 2016). Second, stakeholder interviews were carried out, which main goal is to validate and compliment the desk research findings. The objective and value of the interviews is to shed light on actual forms of coordination and cooperation, something that is neither reflected in official policy documents or organigrams, nor captured by previous research or policy documents - including the author's desk research and analysis.

The primary sources of the first phase (i.e. initial desk research and analysis) include structured keyword search, in English, in peer reviewed publications in leading academic databases, such as Web of Science and Scopus, but also ResearchGate and GoogleSchoolar. The keywords used 
include a variation of governance, eGovernance, eGovernment, citizen, eServices, public service delivery, Denmark, and Japan from 2000 onwards. With only limited results, policy documents from national and international statistical sources were used, such as the International Telecommunications Union (ITU) (2014), UNDESA's eGovernment Readiness Index (2008, 2010, 2012, 2014, 2016), www.internetworldstats.com, and relevant international references (e.g., UN and EU). Several quantitative precondition and effect measurements, like internet availability and penetration, the use of online banking and shopping (i.e., indirect measurements of digital skills), eIDs and a basket of eServices and international benchmarks are included to provide the empirical basis for the effect of a given governance model.

The primary sources for the second phase (i.e. validation and complementation of the initial desk research) are interviews with relevant stakeholders in Denmark and Japan. Semi-structured interviews (i.e., one way of conducting interviews) entails the development of a list of questions on topics, also known as an interview guide (Bryman and Bell 2015). The interviews lasted between 45 and 90 minutes, depending on interviewees' experience and depth of knowledge. All interviewees were sent a written interview guide at least four weeks prior to the scheduled interview. The interview guide included information on the research interview objectives, the list of potential questions covered during the interview, information about confidentiality, privacy, anonymity, data protection, and contact details for the Research Ethics Committee of the University of Tartu if an interviewee should have any ethical concerns (Bryman and Bell 2015). References to interviews are anonymized and the intention to do so was confirmed at the beginning of each interview. The aim of the anonymized interviews is to facilitate as forthcoming answers from the interviewees as possible. The author/interviewer has kept a list of interview dates, times, location, interviewee names, their occupation, contact details, and organisations.

All interviews were recorded following the interviewee(s) acceptance and summary notes were made in writing. Interviews were carried out in-person, bar a few exemptions in Denmark which were carried out by telephone or Skype for logistical reasons. Interviews were either individual or in small groups to ensure efficiency.

In Denmark, all interviews were carried out in Danish (the interviewee is a Danish native speaker). In Japan, all interviews were carried out in a mix of English and Japanese with a professional English-Japanese interpreter accompanying the author/interviewer during all interviews. The interviewer and the English-Japanese interpreter had a short debriefing following each interview to ensure that any culturally specific observations were communicated to the interviewers. The aim of the debriefing was to establish whether interviewees had seemed uncomfortable with the question or tried to avoid giving a straight answer. In general, all Danish and Japanese interviewees were very forthcoming. When the interviews confirm, provide alternative explanations or add additional detail to the desk research (Meyerhoff Nielsen 2016), such information is included and cited in this article.

A total of 16 interviews with 31 interviewees from central and local government, academia, and the private sector were carried out in Denmark (4-11 May 2017) and Japan (29 November - 2 December 2016, and 17 May 2017). The variation in the number of interviews and interviewees is the result of different national set-ups, number of actors and availability, but the mix of 
stakeholders interviewed is similar for both countries. Table 2 outlines the number of interviews as well as the number and type of actors the interviewees represent. 
Table 2: Number and type of interviewees and interviewees per country (source: author)

\begin{tabular}{|c|c|c|c|}
\hline Country & $\begin{array}{l}\text { Number of } \\
\text { interviews }\end{array}$ & $\begin{array}{l}\text { Number of } \\
\text { Interviewees }\end{array}$ & Type and number of interviewees \\
\hline Denmark & 10 & 15 & $\begin{array}{l}6 \times \text { Central government } \\
0 \times \text { Regional government } \\
7 \times \text { Local government } \\
1 \times \text { Academia } \\
1 \times \text { Private sector }\end{array}$ \\
\hline Japan & 6 & 16 & $\begin{array}{l}8 \times \text { Central government } \\
0 \times \text { Regional government } \\
2 \times \text { Local government } \\
4 \times \text { Academia } \\
2 \times \text { Private sector (informal conversation at } \\
\text { GLOCOM) }\end{array}$ \\
\hline
\end{tabular}

\section{4. eGovernment Focus}

ICT has long been used in public administrations in Denmark and Japan, but policy and strategy focus vary, as expected. A historic overview is helpful for comparing the two national governance models.

\section{1. eGovernment in Denmark since 2001}

As a plan for maximizing the ability of management to achieve a set of organizational objectives (Heeks 2005), the Danish eGovernment strategies have followed a similar trajectory as most countries around the world. While the focus has shifted from defining and implementing relevant standards, infrastructure, and services to benefit realization, the key objectives of the Danish eGovernment strategies have been to make Denmark a leading information and knowledge society, and to increase efficiency and productivity while preserving the welfare-state model and associated values (DIGST - Digitaliseringsstyrelsen 2011, Meyerhoff Nielsen 2011, 2016).

The strengthening of cross-governmental cooperation and management in IT projects has been a recurrent theme since 2004. Similarly, data exchange and interoperability has been pursued (Meyerhoff Nielsen 2014, 2016). The initial focus was on the supply of eServices and the roll-put of eID, but the 2011-2015 strategy included cost-savings and benefit realization through mandatory self-service and the business case model.

The $5^{\text {th }}$ eGovernment Strategy for 2016-2020 follows a similar pattern and builds on previous strategies. The focus is on increased effectiveness and usability of eServices, as well as the value added; welfare technologies; private sector growth through public sector digitization, administrative burden reduction, data sharing and reuse (including the once only principle); a more coherent eGovernment framework (i.e., less silos); maintaining and improving the IT infrastructure; privacy and data protection; and improving the management of IT projects and common public programs and efforts (DIGST - Digitaliseringsstyrlesen 2016, Meyerhoff Nielsen 2016). The Danish eGovernment focus since 2001 is summarized in Table 3. 
Table 3: eGovernment in Denmark 2001-2020 (DIGST - Digitaliseringsstyrlesen 2016, Meyerhoff Nielsen 2016)

\begin{tabular}{|c|c|}
\hline $\begin{array}{l}\text { 2001-2003: Digital } \\
\text { collaboration }\end{array}$ & $\begin{array}{l}\text { Allowing citizens to send e-mail to the public sector and authorities to } \\
\text { adopt digital channels of communication. } \\
\text { Examples: digital signatures. }\end{array}$ \\
\hline $\begin{array}{l}\text { 2004-2006: Internal } \\
\text { digitalization and } \\
\text { efficient payments }\end{array}$ & $\begin{array}{l}\text { Focus on secure e-mail between authorities, joint government } \\
\text { standards, and portals. } \\
\text { Examples: eFaktura (eInvoice), NemKonto (single bank account for } \\
\text { government use), Virk.dk (business portal), Sundhed.dk (health } \\
\text { portal), and digital document and archive systems. }\end{array}$ \\
\hline $\begin{array}{l}\text { 2007-2010: Shared } \\
\text { infrastructure and one } \\
\text { point of access }\end{array}$ & $\begin{array}{l}\text { Mandatory use of shared infrastructure; components and standards; } \\
\text { increased cooperation; value added services; and efficiency. } \\
\text { Examples: Borger.dk (the citizen portal), NemID (digital signature), } \\
\text { NemLog-in (single, sign-on), elndkomst (electronic income registry), } \\
\text { Digital Post, NemSMS (SMS service component), and business case } \\
\text { model. }\end{array}$ \\
\hline $\begin{array}{l}\text { 2011-2015: The path to } \\
\text { future welfare }\end{array}$ & $\begin{array}{l}\text { Focus on benefit realization; mandatory use of Digital Post and } \\
\text { selected eServices; reuse of data; increased cooperation. } \\
\text { Examples: data distribution, investment in IT and digital teaching } \\
\text { aids, tested welfare technology, digital literacy, and campaigns. }\end{array}$ \\
\hline $\begin{array}{l}\text { 2016-2020: A stronger } \\
\text { and more secure digital } \\
\text { society }\end{array}$ & $\begin{array}{l}\text { Focus on better, more coherent, user-friendly online services, ICT-led } \\
\text { growth and efficiency, security, cross-government cooperation, and } \\
\text { benefit realization. } \\
\text { Examples: user-journeys for e.g. moving, business reporting and } \\
\text { company registration, administrative burden reduction, once-only- } \\
\text { principle, data driven growth, SMART cities, legal framework, } \\
\text { security, cloud computing, ICT support, and joint service center for } \\
\text { portals and joint-government components like NemID, Digital Post, } \\
\text { etc. }\end{array}$ \\
\hline
\end{tabular}




\section{2. eGovernment in J apan since 1994}

The December 1994 Cabinet "Master plan for promoting government-wide use of IT" can be considered as the first coordinated Japanese national strategy. Clear strategy documents for the promotion of ICT use in public administration and eGovernment have been in place since 1994. Japan initially followed a similar policy path as many other countries. Focus has foremost been on the roll-out of government networks and broadband infrastructure, while focusing on ICT-enabled efficiency and effectiveness initiatives, and public sector reform and governance of ICT initiatives and strategies (Jain 2002, Meyerhoff Nielsen and Igari 2012, Igari 2014, Meyerhoff Nielsen 2016). Similarly, there has been a focus on front-office services and portals. The approach remains unnecessarily complex, with strategies for ICT and open data added in 2010 and 2012, respectively (ITSH - IT Strategic Headquarter 2010, 2012), with limited focus on benefit realization and usability, and only recent emphasis on strengthening the governance model guiding ICT investments (Jain 2002, Meyerhoff Nielsen and Igari 2012, Igari 2014, Meyerhoff Nielsen 2016).

The i-Japan Strategy 2009-2015 has been replaced by the Declaration to be the World's Most Advanced IT Nation for 2016-2020, which was revised in mid-2016. Considering that the introduction of a unique electronic identity (eID) was scheduled for 2013, but was only agreed upon in late 2015, it is not surprising that eIDs are a key focal point of the current strategy. The lack of progress regarding one-stop services, an absence of intergovernmental corporation on ICT issues, and scandals surrounding "missing pensions records", have damaged public confidence in ICT in Japan (Meyerhoff Nielsen and Igari 2012, Hiramoto 2013, Igari 2014, Meyerhoff Nielsen 2016). To address the strategy aims of achieving a safe, secure, and comfortable life for citizens by creating a society in which all citizens are dynamically engaged, the 2016-2020 strategic focus is on breaking down barriers between ministries to achieve cross-cutting coordination, with the Government $\mathrm{CIO}$ acting in a guiding capacity, and the deployment of successful national initiatives to both regional and local level - which are considered promising developments (ITSH IT Strategic Headquarter 2016).

Despite several years in the making and awareness of the potential benefits, Japan still lacks national standards for interoperability and enterprise architecture, and is yet to develop, share or reuse common components and contents - even if the MyNumber eID/Digital Signature is launched and an open data strategy is in place (Meyerhoff Nielsen and Igari 2012). A fact confirmed by multiple interviews in both the public sector (Interview 3 Japan 2016, Interview 4 Japan 2016) and in academia (Interview 1 Japan 2016, Interview 6 Japan 2016). The Japanese eGovernment strategies since 1995 are summarized in Table 4. 
Table 4: eGovernment in Japan 1995-2020 (ITSH - IT Strategic Headquarter 2016, ITSH - IT Strategic Headquarter 2016, Meyerhoff Nielsen 2016)

\begin{tabular}{|c|c|}
\hline $\begin{array}{l}\text { 1995-2000: Master plan } \\
\text { for promoting } \\
\text { government-wide use of } \\
\text { IT (rev. 1997) }\end{array}$ & $\begin{array}{l}\text { ICT-enabled public sector reforms. Promotion of the information } \\
\text { society. } \\
\text { Examples: roll-out. }\end{array}$ \\
\hline $\begin{array}{l}\text { 2001-2003: e-Japan } \\
\text { strategy }\end{array}$ & $\begin{array}{l}\text { Emphasis on key IT infrastructure and use, including broadband } \\
\text { roll-out nationally, increased use of IT and internet, plus eService } \\
\text { development. } \\
\text { Examples: government portal, Public Key Infrastructure (PKI), } \\
\text { establishment of Strategic Steering Committee in PM's office. IT } \\
\text { Basic Law on the formation of an advanced IT network society. }\end{array}$ \\
\hline 2003-2009: e-Japan II & $\begin{array}{l}\text { Focus on eGovernment promotion for increased efficiency and } \\
\text { effectiveness, including ICT-enabled public sector reform. } \\
\text { Examples: one-stop services, optimization plans for business process } \\
\text { and systems. }\end{array}$ \\
\hline 2009-2015: i-Japan II & $\begin{array}{l}\text { Focus on ICT use and solutions at national and local level, in } \\
\text { healthcare and education. Coordination and cooperation for the } \\
\text { implementation of eGovernment, which should be user-centric and } \\
\text { secure. } \\
\text { Examples: eID, digital PO Box, Electronic Health Record, create a } \\
\text { governance structure including appointment of CIOs. }\end{array}$ \\
\hline $\begin{array}{l}\text { 2016-2020: Declaration } \\
\text { to be the World's Most } \\
\text { Advanced IT Nation }\end{array}$ & $\begin{array}{l}\text { Focus on back-office reform, including business process } \\
\text { reengineering and systems elimination (up to } 908 \text { systems) and } 100 \\
\text { billion Yen cost saving. Reform of employment security and } \\
\text { pensions. Front-end services including roll-out of national ID cards } \\
\text { and numbers to improve social security and tax number systems and } \\
\text { user-friendliness. Promotion of safe and secure data exchange, } \\
\text { including open data and cybersecurity. Improvement of national } \\
\text { governance structures. } \\
\text { Examples: eliminate up to } 908 \text { systems, save Yen } 100 \text { billion annually } \\
\text { in operation costs. ID card and eID, launch user-orientated data and } \\
\text { AI platform, updated open data platform. Promote reforms by } \\
\text { Deputy Directors-General for Cybersecurity \& Information } \\
\text { Technology. }\end{array}$ \\
\hline
\end{tabular}




\section{Governance Models and Institutional Frameworks in Place}

Policies and initiatives are developed and carried out differently from country to country. As summarized in Table 5, the general governance and institutional frameworks in Denmark and Japan are no different.

Table 5: General governance and institutional frameworks in Denmark and Japan (Meyerhoff Nielsen 2016)

\begin{tabular}{|l|l|l|}
\hline & Denmark & Japan \\
\hline $\begin{array}{l}\text { National } \\
\text { institutional } \\
\text { framework } \\
\text { and } \\
\text { governance }\end{array}$ & $\begin{array}{l}\text { Centralized model. National, } \\
\text { regional and local government } \\
\text { level. Consists of 5 regions and 98 } \\
\text { municipalities. }\end{array}$ & $\begin{array}{l}\text { Centralized model. National, regional and } \\
\text { local government level. Complex system } \\
\text { of } 47 \text { prefectures, multiple sub-prefectures } \\
\text { and districts, 1719 municipalities of four } \\
\text { “Kanje” types (city, town, ward, non- } \\
\text { municipality). }\end{array}$ \\
\hline $\begin{array}{l}\text { Decentralizat } \\
\text { ion of } \\
\text { government } \\
\text { authority }\end{array}$ & $\begin{array}{l}\text { Large degree of local autonomy } \\
\text { and decision making including tax } \\
\text { and budget spending. C.70-80\% of } \\
\text { citizen services are provided by } \\
\text { municipalities. Degree of central } \\
\text { control via annual budget } \\
\text { negotiations. }\end{array}$ & $\begin{array}{l}\text { National government control prefectures } \\
\text { and municipalities, including tax } \\
\text { collection, borrowing. C. 70\% of budget is } \\
\text { allocated to municipalities. Lack of } \\
\text { progress on intergovernmental } \\
\text { cooperation and decentralization. }\end{array}$ \\
\hline
\end{tabular}

Both countries have centralized institutional frameworks and approaches to governance. Service delivery is largely carried out by local government who has a high level of autonomy. Taxes are set for national, regional, and local level in both countries. In Denmark, this must be within a centrally determined pre-defined band, and collected by the national Tax Agency (Meyerhoff Nielsen and Igari 2012, Meyerhoff Nielsen 2016). In Japan, each level of government sets and collects their own taxes. In Denmark, regions are largely limited to hospitals and some infrastructure delivery. Even if factoring in the population and geographical size of Japan, the organizational complexity is high, with multiple forms of regional and sub-regional authorities. Similarly, Japan's local government structure is complex to navigate with city, town, ward, and even non-municipality "Kanje" types of local authorities (Meyerhoff Nielsen and Igari 2012, Igari 2014). The complexity of Japans institutional framework and governance structures was confirmed by the interviews (Interview 2 Japan 2016, Interview 3 Japan 2016), particularly the academic community (Interview 1 Japan 2016, Interview 6 Japan 2016).

In conclusion, Japan has a more complex institution framework and approach to governance. Intergovernmental cooperation is, by comparison, also less entrenched in Japan as illustrated by both taxation and in eGovernment; such will be illustrated in the coming sections. 


\section{1. eGovernance and Coordination in Denmark since 2010}

Japan and Denmark also take different approaches to governance, decision making, and the degree of cooperation between authorities and levels of government, the private sector, civil society, and research. Despite these differences, similarities also exist. Table 6 summarizes the governance of eGovernment strategies and action plans in Denmark and Japan.

Table 6: eGovernment governance and cooperation models (Meyerhoff Nielsen 2016)

\begin{tabular}{|c|c|c|}
\hline & Denmark & Japan \\
\hline $\begin{array}{l}\text { Responsible } \\
\text { authority for } \\
\text { eGovernment } \\
\text { strategy }\end{array}$ & $\begin{array}{l}\text { Ministry of Finance (MoF), Danish } \\
\text { Agency for Digitization (DIGST) } \\
\text { including the Portfolio Steering } \\
\text { Committee (PSC) for the } \\
\text { eGovernment Strategy. }\end{array}$ & $\begin{array}{l}\text { IT Strategy Council/CIOs Council } \\
\text { (ITSC) and IT Strategic Headquarters } \\
\text { and its national CIO (since 2016) for } \\
\text { the promotion of an Advanced } \\
\text { Information } \\
\text { Telecommunications and } \\
\text { Society (ITSH - IT Strategic } \\
\text { Headquarter), in Cabinet Office. } \\
\text { Regulatory responsibility is in the } \\
\text { Ministry of Internal Affairs and } \\
\text { Communication (MIC). }\end{array}$ \\
\hline $\begin{array}{l}\text { Responsible } \\
\text { authority for action } \\
\text { plan }\end{array}$ & DIGST. & $\begin{array}{l}\text { ITSH and national CIO (since 2016) } \\
\text { responsible for annual priority } \\
\text { policy programs, MIC has the } \\
\text { regulatory responsibility for } \\
\text { eGovernment }\end{array}$ \\
\hline $\begin{array}{l}\text { Responsible } \\
\text { authority for } \\
\text { initiating and } \\
\text { coordinating new } \\
\text { eGov strategies } \\
\text { and action plans }\end{array}$ & DIGST. & ITSH, in principle. \\
\hline $\begin{array}{l}\text { Chairperson } \\
\text { organization }\end{array}$ & DIGST on behalf of MoF. & $\begin{array}{l}\text { PM chairs ITSC and ITSH but not } \\
\text { MIC, whose responsible minister is a } \\
\text { member, despite the regulatory } \\
\text { responsibility. National CIO at ITSH } \\
\text { (since 2016) is responsible for } \\
\text { meetings. }\end{array}$ \\
\hline $\begin{array}{l}\text { Hosting } \\
\text { organization and } \\
\text { secretariat }\end{array}$ & DIGST. & $\begin{array}{l}\text { Cabinet office host ITSC and the } \\
\text { ITSH, but ITSC and ITSH is } \\
\text { physically located in a building of }\end{array}$ \\
\hline
\end{tabular}




\begin{tabular}{|c|c|c|}
\hline & & $\begin{array}{l}\text { the MIC (Interview } 2 \text { Japan 2016, } \\
\text { Interview } 3 \text { Japan 2016) }\end{array}$ \\
\hline $\begin{array}{l}\text { Member } \\
\text { organizations }\end{array}$ & $\begin{array}{l}\text { Representatives from MoF (i.e. } \\
\text { DIGST), key ministries like } \\
\text { economy, taxation, justice, science, } \\
\text { health and interior, Danish Regions } \\
\text { (DR) and Local Government } \\
\text { Denmark (LGDK). }\end{array}$ & $\begin{array}{l}\text { PM, Chief cabinet secretary, MIC, } \\
\text { Minister of Posts and } \\
\text { Telecommunications, Minister of } \\
\text { International Trade and Industry, } \\
\text { plus other key ministries. IT and } \\
\text { technology industry representatives } \\
\text { and academia represented. }\end{array}$ \\
\hline $\begin{array}{l}\text { National } \\
\text { eGovernance and } \\
\text { cooperation model }\end{array}$ & $\begin{array}{l}\text { Centralized with mixed features, } \\
\text { i.e. process driven by DIGST but } \\
\text { representatives from all levels of } \\
\text { government, initiatives from all } \\
\text { stakeholders, consultative and } \\
\text { consensus based with a strong } \\
\text { mandate. }\end{array}$ & $\begin{array}{l}\text { Hybrid, i.e. centralized in relation to } \\
\text { strategy and policy development, } \\
\text { but decentralized and uncoordinated } \\
\text { in relation to prefectures and } \\
\text { municipalities - not represented on } \\
\text { ITSC or in ITSH. MIC has regulatory } \\
\text { responsibility for eGovernment. } \\
\text { Weak ITSH mandate compared to } \\
\text { MIC. In practice, the ITSC and ITSH } \\
\text { are located in the MIC building and } \\
\text { a large number of staff is on loan } \\
\text { from MIC leading to a high level of } \\
\text { informal coordination and a } \\
\text { minimisation of potential conflicts } \\
\text { (Interview } 1 \text { Japan 2016, Interview } 2 \\
\text { Japan 2016, Interview } 3 \text { Japan 2016, } \\
\text { Interview } 6 \text { Japan 2016) }\end{array}$ \\
\hline $\begin{array}{l}\text { Process of } \\
\text { eGovernment } \\
\text { strategy and action } \\
\text { plan development } \\
\text { and approval } \\
\text { (from idea to } \\
\text { approval by } \\
\text { government) }\end{array}$ & $\begin{array}{l}\text { Centralized process coordinated by } \\
\text { DIGST but in consultation with all } \\
\text { relevant state holders including } \\
\text { key ministries, DR and LGDK, } \\
\text { private and civic interest groups. }\end{array}$ & $\begin{array}{l}\text { Centralized process coordinated by } \\
\text { ITSH and with consultation of large } \\
\text { IT and technology companies. MIC } \\
\text { and other strong ministries does not } \\
\text { necessarily comply with ITSH. Lack } \\
\text { consultation with prefecture, } \\
\text { municipalities and other interests. }\end{array}$ \\
\hline eGovernment & Yes, part of the government & Yes, part \\
\hline
\end{tabular}




\begin{tabular}{|l|l|l|}
\hline strategy legality & program. & program. \\
\hline $\begin{array}{l}\text { Action plan (i.e. is } \\
\text { the strategy } \\
\text { underpinned by an } \\
\text { action plan) }\end{array}$ & Yes. & $\begin{array}{l}\text { No, annual policy priorities program } \\
\text { in place for e-Japan II 2003-2009 but } \\
\text { and again for 2016-2020 strategy } \\
\text { including KPIs. }\end{array}$ \\
\hline $\begin{array}{l}\text { Action plan legally } \\
\text { binding }\end{array}$ & $\begin{array}{l}\text { Yes, is part of the government } \\
\text { program and annual budget } \\
\text { negotiations between all levels of } \\
\text { government. }\end{array}$ & No. \\
\hline
\end{tabular}

In Denmark, the governance model has evolved over time. The governance and management model has been the subject of review with each passing eGovernment strategy and has been adapted over time (Meyerhoff Nielsen 2016), and confirmed by multiple interviews including representatives from local government (Interview 3 Denmark 2017), central government (Interview 6 Denmark 2017), and academia (Interview 8 Denmark 2017).

Since 2010, DIGST has been responsible for eGovernment strategies and action plans and their daily coordination. This includes a mandate to initiate and ensure benefit realization and compliance. DIGST was established following a merger of the key government players, including the Digital Taskforce (established in 2005) and hosted by the Ministry of Finance, the Agency for Governmental Management, and the eGovernment related standards, infrastructure and platforms from the National IT- and Telecom Agency. Policy documents and past research highlight that the aim was to improve the efficiency and effectiveness of the governance model (DIGST Digitaliseringsstyrelsen 2011, Meyerhoff Nielsen 2011, 2014, 2016). Interviews with representatives from both local (Interview 3 Denmark 2017, Interview 5 Denmark 2017) and central government (Interview 6 Denmark 2017) confirm the aim and the practice.

Since the 2010 eGovernment strategy onwards, decision making has largely been made at the Steering Committee for the eGovernment strategy (SC). The SC meets 10-12 times annually, is chaired by DIGST on behalf of the Ministry of Finance, and consists of representatives (generally directors and key unit heads) from key ministries, plus Danish Regions (DR), and the Local Government of Denmark (LGDK) (Meyerhoff Nielsen 2011, 2014, 2016). A practice confirmed by interviews with the representatives from the local government (Interview 3 Denmark 2017) and the coordinating agency (Interview 6 Denmark 2017).

In 2016, the name and mandate of the Steering Committee for eGovernment has been strengthened. The new Portfolio Steering Committee (PSC) (i.e. Portføljestyregruppe in Danish) is a continuation of the previous SC and has overall responsibility for executing the eGovernment strategy and its initiatives, i.e. incorporates the previously held Joint Committee for Cross 
Government Cooperation (STS) mandate (DIGST - Digitaliseringsstyrlesen 2016). ${ }^{1}$ The PSC is now also responsible for the realignment of the strategic direction of the joint-governmental use of ICT and digitisation, e.g. due to technological development. Each year, a status report on progress, effect, and agreed goals for the digitization strategy is prepared by individual initiatives. Like its predecessor, the PSC is assembled 10-12 times annually (DIGST - Digitaliseringsstyrlesen 2016). Interviews with local government (Interview 3 Denmark 2017) and the coordinating agency (Interview 4 Denmark 2017, Interview 6 Denmark 2017) highlight the importance of the adjustment as a way to strengthen operational and daily coordination and the efficiency of the governance model.

For each of the eGovernment action plan initiatives, a programme or project steering committee or workgroup are established (by the joint governmental PSC) to ensure successfully implementation. The aim is to ensure proper coordination of individual elements in a given programme or project, ensure ownership across partners, and minimise the risk of unsuccessful completion through decentralised decision making. The individual programme and project steering committees and working groups report to SC on a monthly basis and can escalate issues to the forum. The SC is supported by two standing committees on legal issues (i.e. Stående udvalg om juridisk spørgsmål), and financial and budgetary (i.e. Økonomiudvalg) issues, respectively. The legal committee assists by providing suggestions for realignment of regulations and legal provisions to facilitate increased ICT use and also re-use of data between authorities. The financial and budgetary committee is tasked with the overall responsibility for the ongoing financial management of the eGovernment strategy, including management of under- and over-spending at the initiative level and any proposals for spending adjustments on a yearly basis (DIGST -

1 The Joint Committee for Cross Government Cooperation (STS) was established in 2010 and operated until 2015, when its mandate was incorporated into the new Steering Committee (i.e. Portføljestyregruppe) DIGST - Digitaliseringsstyrlesen (2016). Governance. Copenhagen, DIGST - Digitaliseringsstyrelsen.. The STS was chaired by the Ministry of Finance and met approximately four times per year. It consists of permanent secretaries sitting in the cabinet committees for coordination and economic affairs and management committees of DR and LGDK. The STS members thus advise the individual ministers in the cabinet before an eGovernment strategy is presented to the parliament for approval by the Minister of Finance, on behalf of the government. For national strategies and reform program there is a tradition to have broad parliamentary support, including from opposition, to ensure continuity in the strategic direction of the country Meyerhoff Nielsen, M. (2011). "Danish eGovernment Success Factors: Strategies and Good Practice Examples." Global Strategy and Practice of E-Governance: Examples from Around the World: Examples from Around the World: 231, Meyerhoff Nielsen, M. Y., Mika (2014). "An analysis of the Danish approach to eGovernment benefit realisation." Internet Technologies and Society 2014 Conference Proceedings: 47-58, Meyerhoff Nielsen, M. (2016). Governance and online service delivery: The Danish case. Electronic Government and Electronic Participation, Guimaraes, IOS Press. The role of STS has over time changed from including implementation and management issues to the strategic approval of a given vision, eGovernment strategy, its action plan and associated budget as well as its completion and was discontinued with the 2016-2020 eGovernment strategy DIGST - Digitaliseringsstyrlesen (2016). Et stærkere og mere trygt digitalt samfund: Den fællesoffentlige digitaliseringsstrategi 2016-2020. Copenhagen, DIGST - Digitaliseringsstyrelsen, DIGST - Digitaliseringsstyrlesen. (2016). "Digitaliseringsstyrelsen." Retrieved 25 March 2016, 2016, from www.digst.dk , DIGST Digitaliseringsstyrlesen (2016). Governance. Copenhagen, DIGST - Digitaliseringsstyrelsen.. 
Digitaliseringsstyrlesen 2016, Interview 6 Denmark 2017). This is, in part, underpinned by the use of the joint-governmental IT programme and project model, which is mandatory for initiatives exceeding DKK 10 million (c. $€ 1.3$ million) with a large ICT component (Meyerhoff Nielsen 2014).

While DIGST, since 2016, has been guided by the Minister for Public Sector Innovation, said minister operates within the Ministry of Finance. In practice, the newly establish PSC continues to be chaired by DIGST on behalf of the Ministry of Finance, with members from key central government actors responsible for business, growth, justice, education, interior affairs, regional and local government (DIGST - Digitaliseringsstyrlesen 2016, DIGST - Digitaliseringsstyrlesen 2016). Interviews with multiple actors from local and central government confirms the practice (Interview 3 Denmark 2017, Interview 4 Denmark 2017, Interview 5 Denmark 2017, Interview 6 Denmark 2017, Interview 10 Denmark 2017). To bring a sense of order and oversight to the Danish eGovernance model responsibilities, information flows and decision making is formalized as illustrated by decision making flows in the official organigram in Figure 1 and overview of strategic intiatives illustrated in Figure 2. A formalized approach is particularly important as the number of initiatives with steering committees and working groups in the action plan adds complexity to the Danish approach, as illustrated by the official organigram in Figure 2 (in Danish).

Figure 1: Organigram of the eGovernment strategy, Portfolio Steering Committee and project steering committee in Denmark 2016-2020 (DIGST - Digitaliseringsstyrlesen 2016) 


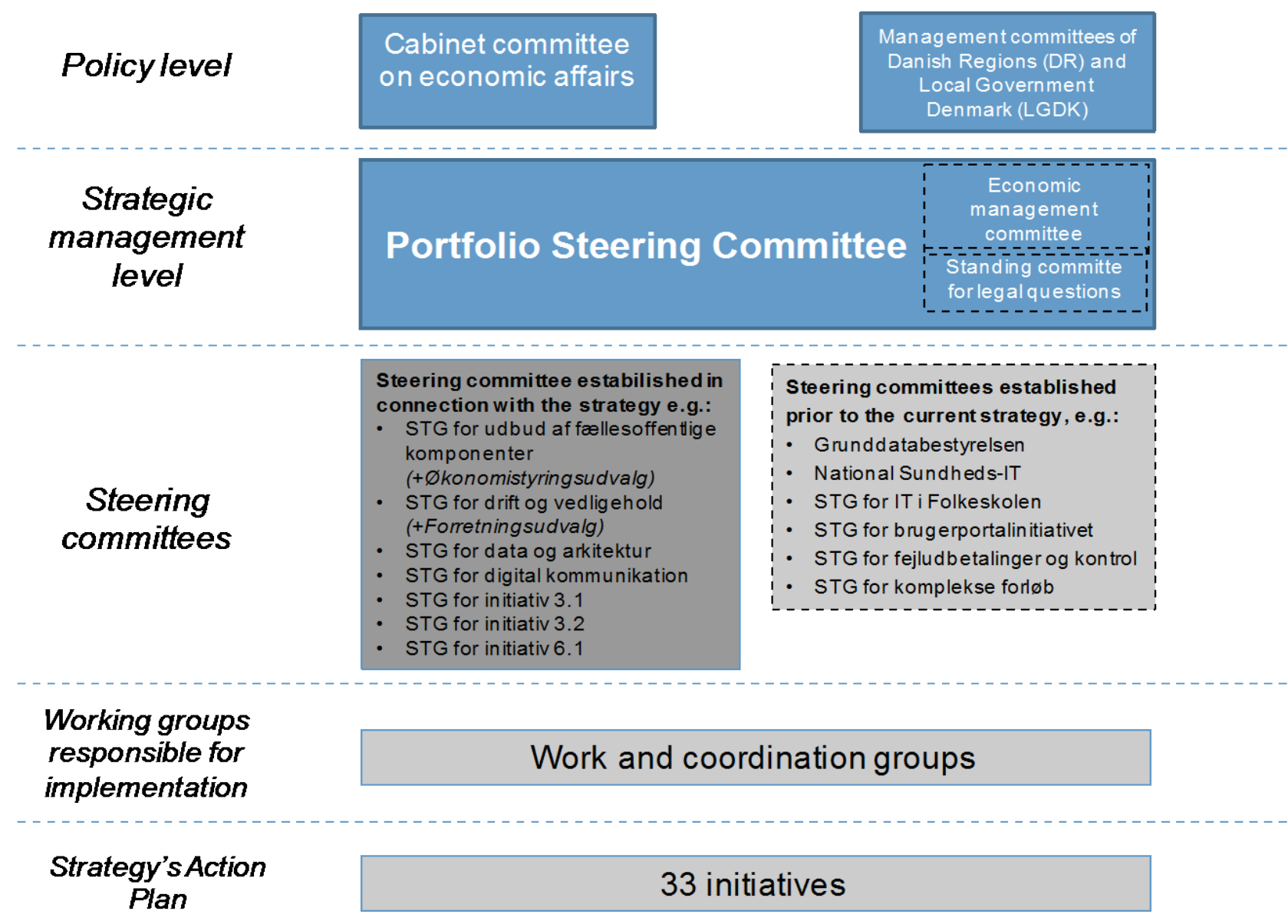

Figure 2: Overview of the eGovernment strategy initiatives, Portfolio Steering Committee and project steering committee in Denmark 2016-2020 (DIGST - Digitaliseringsstyrlesen 2016) 


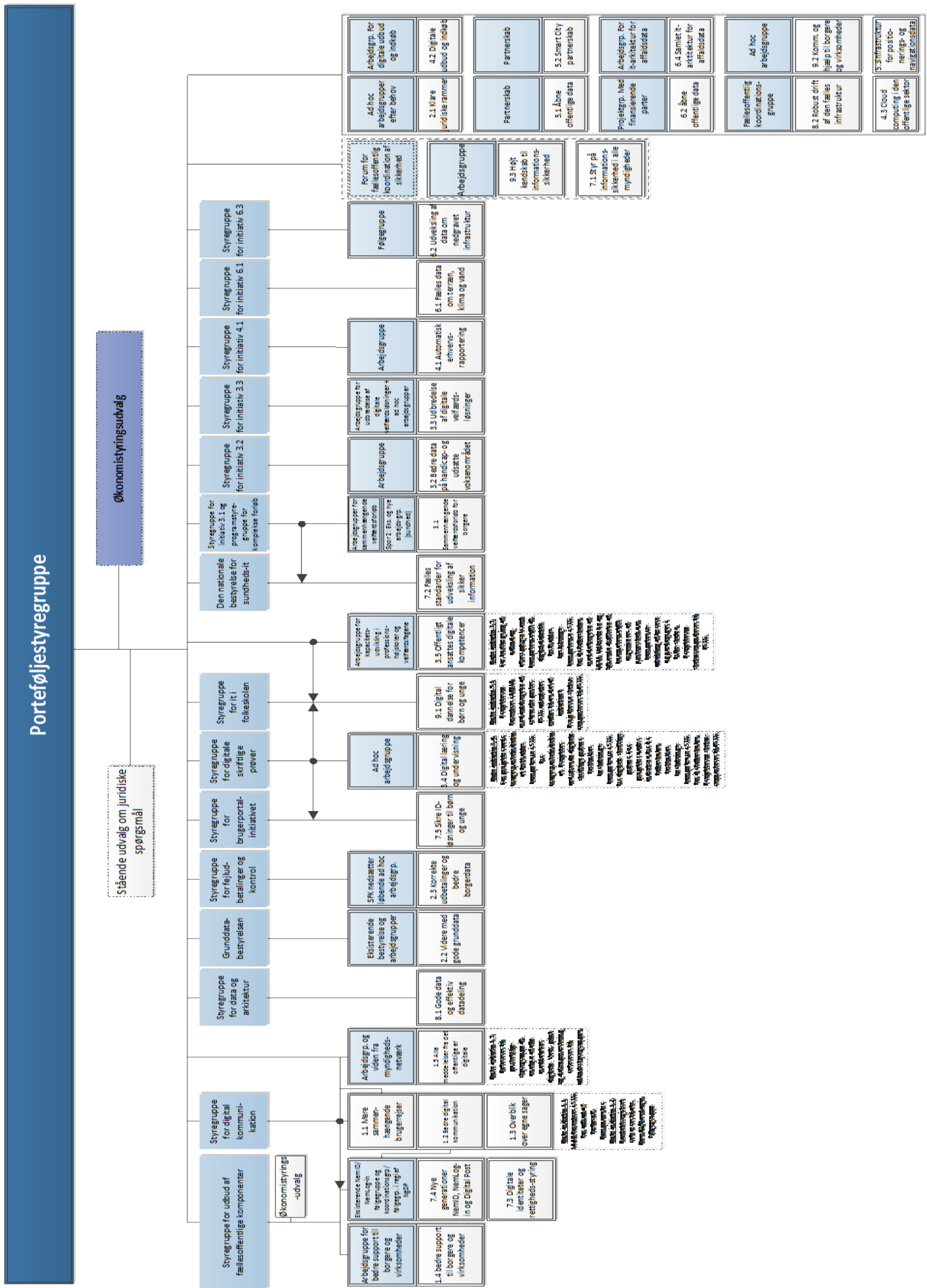

Stakeholders directly involved in the PSC and in the eGovernment strategy's action plan include key central government actors responsible for social services, tax, interior, education, 
health, core registers, cadastral data, the management committees of umbrella organisations of Danish Regions and Local Government of Denmark. As confirmed by policy documents (DIGST Digitaliseringsstyrlesen 2016, DIGST - Digitaliseringsstyrlesen 2016), previous research (Meyerhoff Nielsen and Igari 2012, Meyerhoff Nielsen 2016, 2016), and academic interviews (Interview 8 Denmark 2017), citizens, businesses or academia are not directly represented in any aspects of the formal governance model. That said, interviews with local government actors (Interview 3 Denmark 2017, Interview 5 Denmark 2017, Interview 7 Denmark 2017), central government and the coordinating agency (Interview 1 Denmark 2017, Interview 4 Denmark 2017, Interview 8 Denmark 2017) show that with every new strategy and action plan, formal and informal consultation is carried out by DIGST. Interviewees from academia (Interview 8 Denmark 2017) and the private sector (Interview 2 Denmark 2017) confirm that stakeholders indirectly involved includes the IT sector (e.g. Dansk ITs politiske udvalg for IT i den offentlige sector and the Danish IT-industry's political committee for IT in the public sector), the private sector (e.g. Danish Industry), and citizen groups (e.g. senior citizen representatives). Similarly, private vendors contracted for the implementation of individual initiatives generally participate in the relevant programme and project steering committees and working groups. Both aspects are confirmed by interviews with local (Interview 3 Denmark 2017, Interview 5 Denmark 2017, Interview 7 Denmark 2017) and central government representatives. (Interview 1 Denmark 2017, Interview 4 Denmark 2017, Interview 8 Denmark 2017).

On an operational level, the current strategy has formally introduced the concept of programme and project steering committees and working groups. Interviews emphasized that the change was introduced to facilitate greater coordination between initiatives with inter-dependencies and provide more clarity (Interview 3 Denmark 2017, Interview 6 Denmark 2017). Interviews confirmed that DIGST is open to, and actively encourages, participation from central, regional and local authorities in individual initiatives (Interview 2 Denmark 2017, Interview 3 Denmark 2017, Interview 4 Denmark 2017, Interview 5 Denmark 2017, Interview 7 Denmark 2017, Interview 9 Denmark 2017, Interview 10 Denmark 2017). Authorities seem to limit their engagement due to resource constraints. Several authorities indicated in their interviews that they focus their resources on those initiatives where they deem to have most at stake in shaping the outcomes, the most insight and knowledge (Interview 7 Denmark 2017, Interview 9 Denmark 2017, Interview 10 Denmark 2017). Despite the general openness, interviewees at local level (Interview 7 Denmark 2017, Interview 9 Denmark 2017) and in academia (Interview 8 Denmark 2017) highlighted that the experienced level of transparency and consultation is unclear and hard to figure out, when the strategy and action plan initiatives is initially. The stakeholders involved in the Danish eGovernance model is illustrated in Figure 3. 
Figure 3: Stakeholders in the Danish eGovernance and coordination model (source: author)

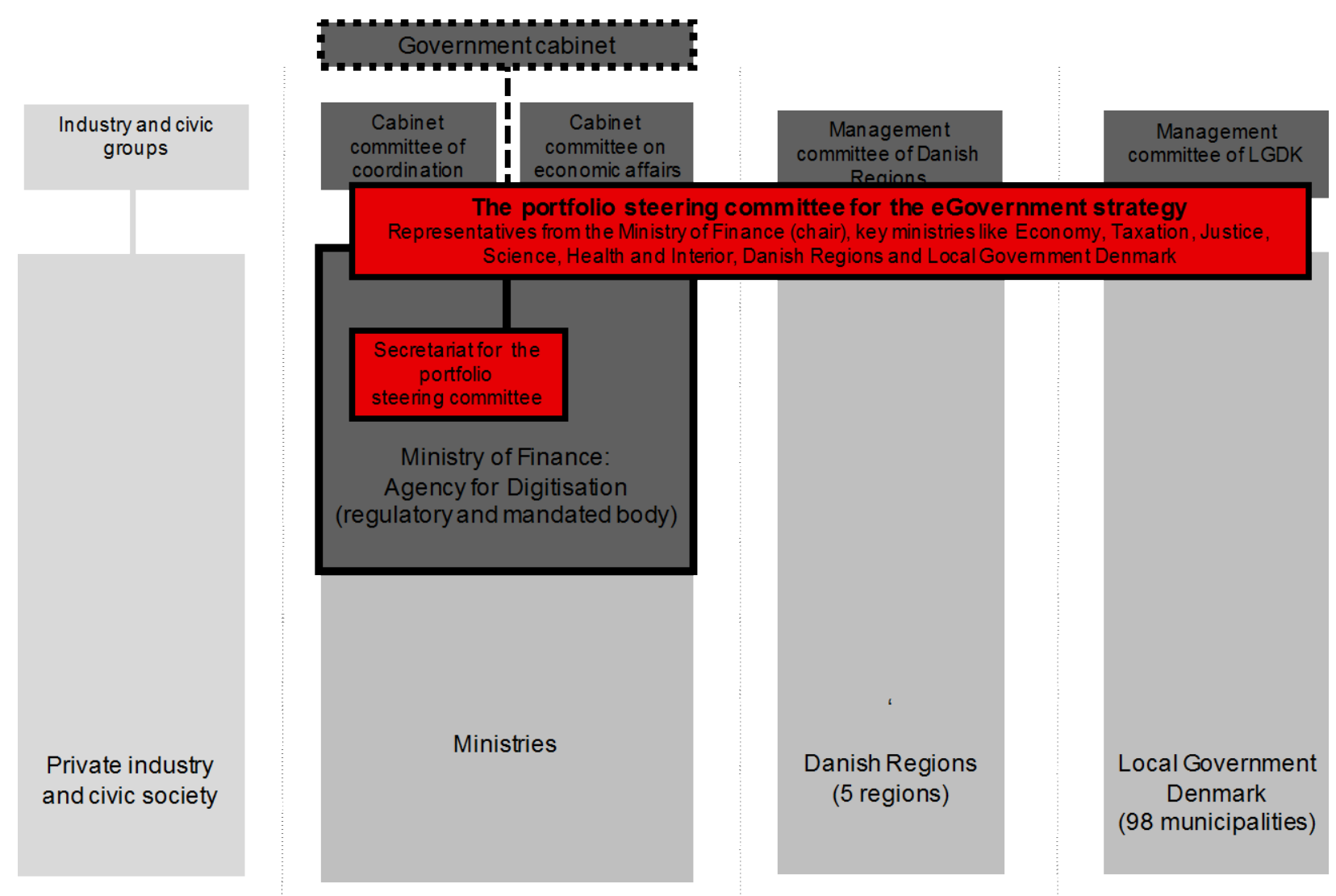

In conclusion, the strength of the eGovernance model is the cyclical evaluation and strengthening with each eGovernment strategy. The strong mandates and roles of DIGST and the PSC (including the past Steering Committee) are key in Denmark's eGovernment successes. The joint-governmental nature helps create a joint vision and ownership to the national vision, strategy, and action plans. Similarly, the link between goals and KPIs in the strategy and individual initiatives help ensure successful implementation and benefit realization, in part assisted by the joint-governmental IT-programme and -project model. While formal and informal consultations are the norm for new eGovernment strategies, it is unfortunately the private sector, academia, and select end-user groups that are not formally part of the eGovernance model, as this could help ensure a more holistic approach to ICT use in public administration and focus, including breaking down organizational barriers to the benefit of citizens and businesses. Similarly, consultation and transparency for new strategies, and particularly on the envisaged focus and outcomes of action plan initiatives, could be strengthened in relation to local authorities and non-governmental stakeholders.

\section{2. eGovernance and Coordination in J apan since 2001}

Since January 2001, the IT Strategic Headquarter (ITSH) has been Japan's mandated body and key eGovernment coordinator. The ITSH is located in the cabinet office and acts as the secretariat for 
the IT Strategic Council/CIOs Council (established in September 2002 and henceforth ITSC), the planning board (established March 2010), and several committees.

With the 2016-2020 declaration, a national Government CIO position was created within the ITSH. The new government CIO is tasked with the guidance of the national eGovernment strategy, including cooperation with relevant headquarters and the development and management of evaluation indicators for monitoring of progress (including KPIs for the strategy). Similarly, the government $\mathrm{CIO}$ evaluates the IT-related measures of ministries and agencies, proposes a revision of existing initiatives and goals within the overall framework, and budgets the eGovernment strategy (Kantei 2015, Interview 1 Japan 2016, Interview 2 Japan 2016, Interview 3 Japan 2016, ITSH - IT Strategic Headquarter 2016, ITSH - IT Strategic Headquarter 2016).

The Ministry of Internal Affairs and Communication (MIC) is a regulatory authority responsible for ICT, including prefectures and municipalities. Selected representatives from large IT and technology firms and academia are represented in the ITSC (Figure 4). An analysis of official policy documents and organigrams shows that roles, responsibilities. and mandates of the planning board in decision-making, and in relation to the ITSC and the government CIOs appointed in August 2012, is somewhat ambiguous. Subsequent interviews with academics (Interview 1 Japan 2016, Interview 6 Japan 2016), central government and the coordinating agency (Interview 2 Japan 2016, Interview 3 Japan 2016) highlight that the government CIO is responsible for coordination, however, lacks mandate to ensure compliance with the national vision or eGovernment strategy. While the different mandates and regulatory responsibilities between the ITSH and MIC look like a source of potential conflicts of interest and confused mandates (Jain 2002, Meyerhoff Nielsen and Igari 2012, Igari 2014, ITSH - IT Strategic Headquarter 2016), in practice, the potential conflict between the ISTH and MIC is minimal, as the ISTH is physically located in the MIC rather than the cabinet building. At the same time, a large number of ISTH staff is seconded from the MIC and other key authorities, such as the Ministry of Tax, as confirmed by interviews with both government actors, the coordinating agency (Interview 2 Japan 2016, Interview 3 Japan 2016, Interview 5 Japan 2016), and academics (Interview 1 Japan 2016, Interview 6 Japan 2016).

There is no clear link between the national eGovernment strategy and initiatives, and those at relation and local level. Similarly, there is no national IT programme and project model in place to ensure risk minimization and benefit realisation (ITSH - IT Strategic Headquarter 2016, Kantei 2016, JiJI 2017, MIC - Ministry of Internal Affairs and Communications 2017). That said, interviews with both central government actors (Interview 2 Japan 2016, Interview 3 Japan 2016, Interview 5 Japan 2016) and academics (Interview 1 Japan 2016, Interview 6 Japan 2016) indicate that most authorities form some sort of project management model. The Japanese eGovernance model is illustrated in Figure 4. 
Figure 4: Organigram of eGovernment promotion in Japan since 2003 (MIC - Ministry of Internal Affairs and Communications 2017)

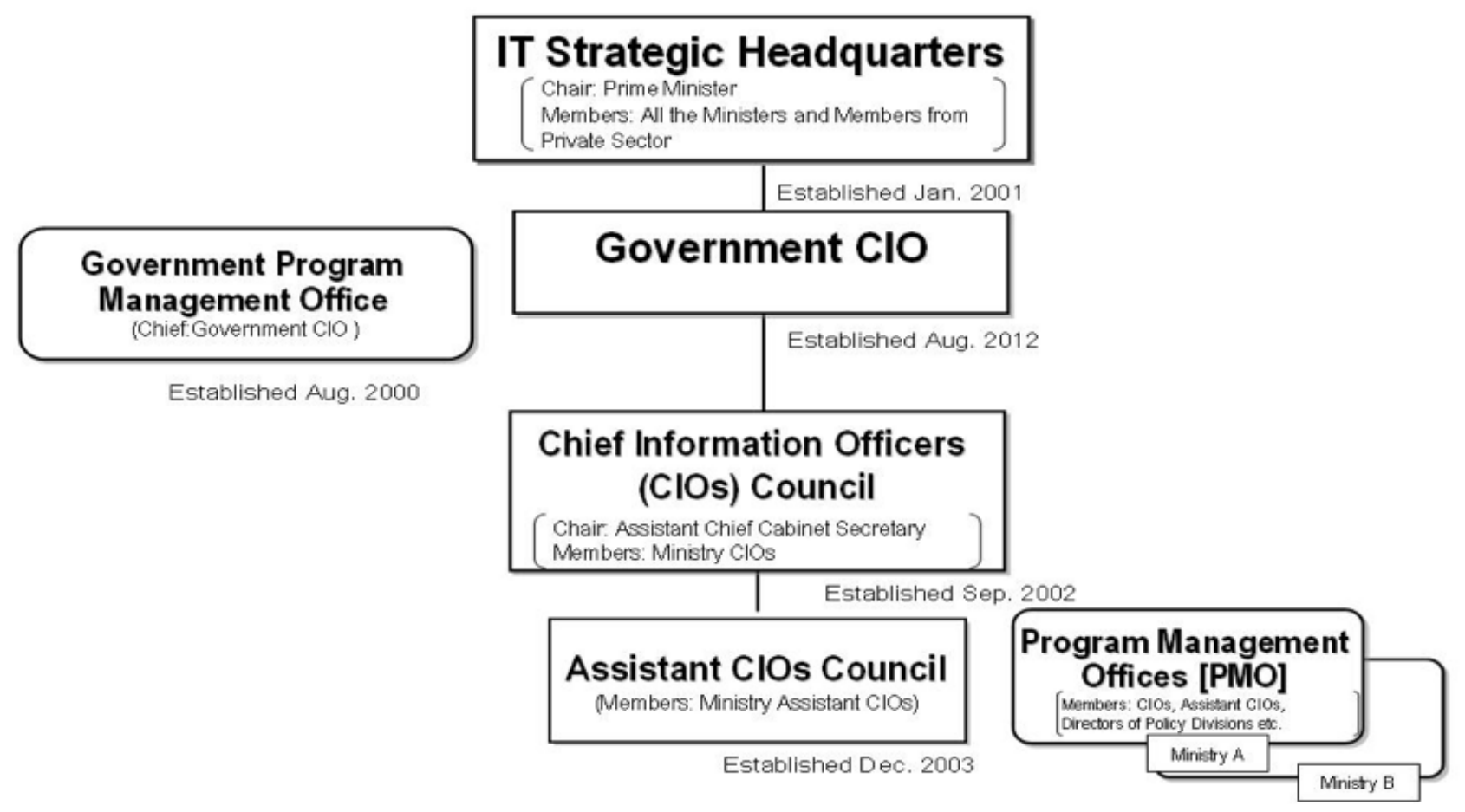

Stakeholders directly involved include key government agencies. Selected representatives from large IT and technology firms and academia are also invited to partake in the ITSC. Policy documents, official websites, and past research show that prefectures and municipalities are not represented in the ITSH, ITSC, planning board, or committees (ITSH - IT Strategic Headquarter 2016, ITSH - IT Strategic Headquarter 2016, Bureau 2017). Interviews with both government officials (Interview 2 Japan 2016, Interview 3 Japan 2016, Interview 5 Japan 2016) and academics (Interview 1 Japan 2016, Interview 6 Japan 2016), indicate that prefectures and municipalities are indirectly represented by the MICs Local Administration Bureau (LAB), which is responsible for regional decentralization, including ICT related issues, but has limited power to enforce actual compliance in situations where MIC or LAB are not the funding source. Interviewees highlighted that an ex-MIC and ITSH employee is now the major of Kurashiki City - a medium-sized city of 450.000 people in Okayama prefecture - and thus indirectly represents local government, but that it is an incidental rather than calculated decision (Interview 1 Japan 2016, Interview 3 Japan 2016). Interviews also confirmed that stakeholders, such as citizens and businesses, or small and medium sized IT companies, are not represented in the ITSC except though central government authorities (Interview 1 Japan 2016, Interview 2 Japan 2016, Interview 3 Japan 2016). The stakeholders involved in the Japanese eGovernance model is illustrated in Figure 5. 
Figure 5: eGovernment governance and coordination model in Japan (source: author)

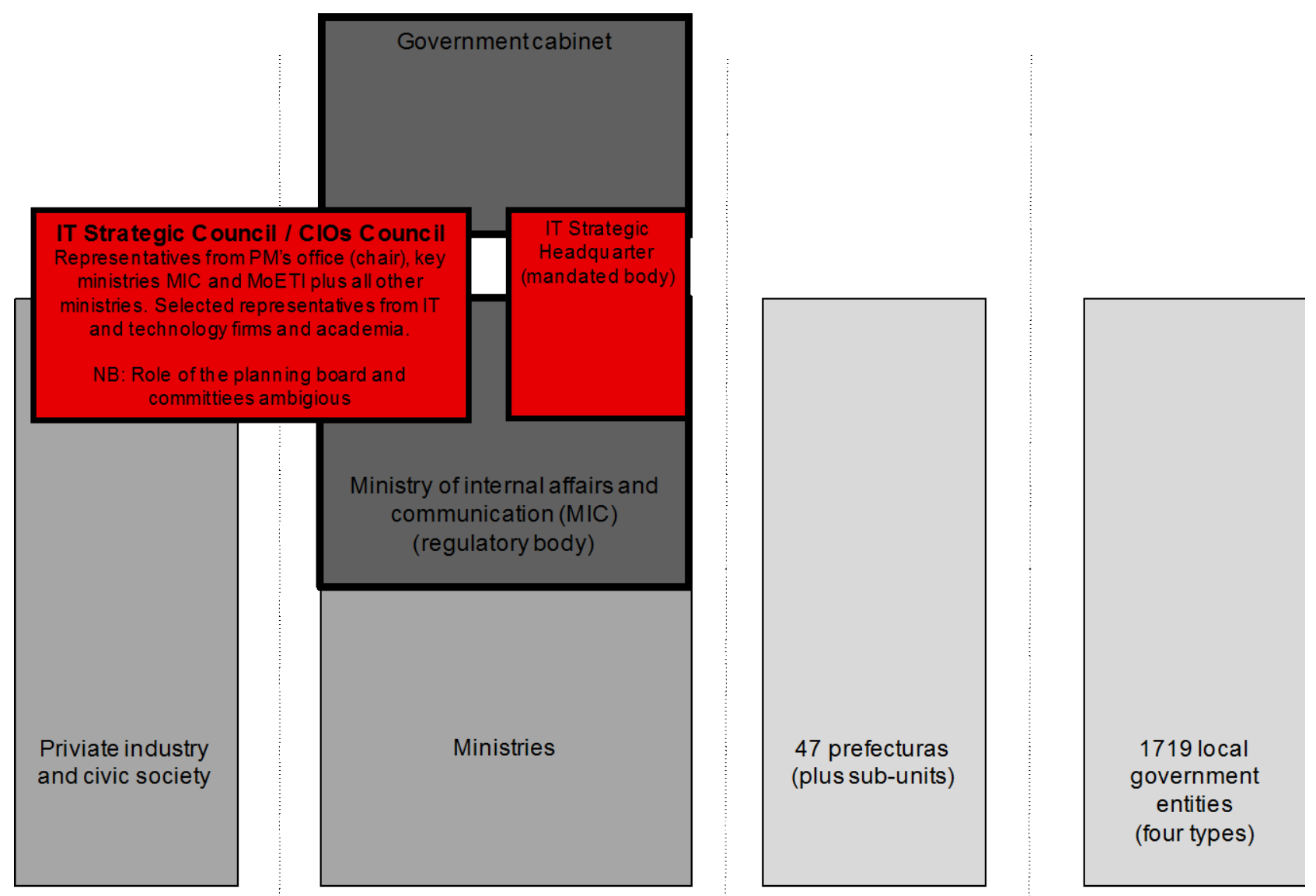

In conclusion, the relative consistent approach to eGovernance can be considered a strength. While the division of the mandatory and regulatory mandates on paper can be seen as a weakness, the physical location of the ITSH and ITSC (the mandated bodies) within the MIC (the regulatory body), and the high number of ITSH staff on loan from MIC and other ministries, all minimize the risk of conflict. The informal nature of these networks would benefit from formalization. While academia and private industry representation in the ITSC is a strength, the domination of large hardware and infrastructure companies should be diluted to ensure that also software and other ICT applications come to the forefront. A key weakness of the Japanese eGovernance model is the lack of direct regional and local government representation in both the ITSH and ITSC. Informal, indirect, and accidental representation by key public service providers should be formalized to ensure that the national eGovernment vision covers all levels of government. The annual evaluation of eGovernment initiatives is a strength of the Japanese approach, but the seemingly lack of measurable eGovernment objectives, which in turn can be linked to individual activities, remains a weakness when it comes to benefit realisation.

\section{Internet Access, Key Enablers, Citizen eServices, and Use and Impact}

Having outlined the eGovernment strategies of Japan and Denmark, as well as their respective governance and cooperation models, the question now is what the two countries achieved in terms 
of internet access, key enablers and citizen eServices rolled-out (supplied), and whether these have led to the envisioned impacts (demand and use).

\subsection{Internet Access and Use}

Access to, and the skills to use, the internet are prerequisites for a successful eGovernment and the uptake of provided eServices. Both Denmark and Japan have successfully rolled out internet infrastructure, as illustrated in Table 7. The two countries have similarly high rates of mobile and broadband subscription rates $(122.89 \% / 42.75 \%$ and $129.75 \% / 31.47 \%$ in Denmark and Japan, respectively). OECD data from 2014 shows that broadband prices are lower in Japan (at US\$ 21.74 - 51.96) than in Denmark (at US\$ 22.24 - 62.68, both adjusted to purchasing price parity). Japan also offers faster internet speeds and uses superior technology (such as FTTH, Fiber/LAN and fiber connections) than Denmark (OECD 2016).

Table 7: Number of mobile and broadband subscriptions per 100 inhabitants 2000-2016 (selected years) (ITU - Internet Telecommunications Union 2017)

\begin{tabular}{|l|l|l|l|l|l|}
\hline & $\mathbf{2 0 0 0}$ & $\mathbf{2 0 0 5}$ & $\mathbf{2 0 1 0}$ & $\mathbf{2 0 1 5}$ & $\mathbf{2 0 1 6}$ \\
\hline Denmark & $63,01 / 1,26$ & $100,58 / 24,80$ & $115,67 / 38,44$ & $125.04 / 42.48$ & $12.89 / 42.75$ \\
\hline Japan & $53,12 / 0,68$ & $75,98 / 18,35$ & $96,81 / 28,04$ & $126.54 / 30.65$ & $129.75 / 31.47$ \\
\hline
\end{tabular}

Similarly, government policies have facilitated the development of a digitally literate population and society (96.97\% in Denmark and 92\% in Japan, in 2016), as illustrated by the growth of internet use since 2000 in Table 8.

Table 8: Individual use of the internet per 100 inhabitants 2000-2016 (selected years) (ITU - Internet Telecommunications Union 2017)

\begin{tabular}{|l|l|l|l|l|l|}
\hline & $\mathbf{2 0 0 0}$ & $\mathbf{2 0 0 5}$ & $\mathbf{2 0 1 0}$ & $\mathbf{2 0 1 5}$ & $\mathbf{2 0 1 6}$ \\
\hline Denmark & 39,17 & 82,74 & 88,72 & 96,33 & 96,97 \\
\hline Japan & 29,99 & 66,92 & 78,21 & 91,06 & 92,00 \\
\hline
\end{tabular}

\subsection{Key Enablers and eServices}

Data for citizens' use of key enablers, such as electronic identities (eIDs), digital signatures and the volume of public service delivery online, is readily available for Denmark for the 2012-2016 period, but was more difficult to obtain for Japan, as illustrated in Table 9. 
Table 9: Individual use of eServices 2000-2014, selected year, as a percentage of overall service volume (MIC 2012, NIA - National Tax Agency Japan 2015, Kantei 2016, DIGST - Digitaliseringsstyrlesen 2017)

\begin{tabular}{|c|c|c|c|c|c|c|c|c|}
\hline & \multicolumn{2}{|c|}{$\begin{array}{l}\text { eService } \\
\text { availability }\end{array}$} & \multicolumn{6}{|c|}{$\begin{array}{l}\text { Degree of digitization (i.e. } \% \text { of service delivery volume } \\
\text { online) }\end{array}$} \\
\hline & & & 2012 & & 2015 & & 2016 & \\
\hline & Denmark & Japan & Denmark & Japan & Denmark & Japan & Denmark & Japan \\
\hline $\begin{array}{l}\text { eID / } \\
\text { eSignature }\end{array}$ & NemID & yes & 79.1 & -- & 89.2 & 7.7 & 92 & 9.2 \\
\hline Digital post & $\begin{array}{l}\text { Digital } \\
\text { Post }\end{array}$ & no & -- & -- & 89.2 & -- & 90.1 & -- \\
\hline $\begin{array}{l}\text { Tax } \\
\text { declaration } \\
\text { simple/ } \\
\text { expanded }\end{array}$ & yes/yes & yes & $100 / 96$ & 48.9 & $100 / 99$ & $56.5^{2}$ & $100 / 99$ & $58.6^{2}$ \\
\hline $\begin{array}{l}\text { Register for } \\
\text { school }\end{array}$ & yes & $\mathrm{n} / \mathrm{a}$ & 57 & -- & 96 & -- & 97 & -- \\
\hline $\begin{array}{l}\text { Register for } \\
\text { university }\end{array}$ & yes & $\mathrm{n} / \mathrm{a}$ & 80 & -- & 100 & -- & 100 & -- \\
\hline $\begin{array}{l}\text { Apply for } \\
\text { student grant } \\
\text { / repay }\end{array}$ & yes/yes & $\mathrm{n} / \mathrm{a}$ & $100 / 54$ & -- & $100 / 92$ & -- & $100 / 923$ & -- \\
\hline $\begin{array}{l}\text { Change } \\
\text { address }\end{array}$ & yes & yes & 63 & $\begin{array}{l}0.0000 \\
021\end{array}$ & 92 & -- & 92 & -- \\
\hline $\begin{array}{l}\text { Housing } \\
\text { subsidy }\end{array}$ & yes & $\mathrm{n} / \mathrm{a}$ & 77 & -- & 79 & -- & 79 & -- \\
\hline Pension & yes & yes & 94 & -- & 95 & -- & 95 & -- \\
\hline $\begin{array}{l}\text { Apply for } \\
\text { national / EU } \\
\text { health card }\end{array}$ & yes/yes & $\mathrm{n} / \mathrm{a}$ & $43 / 65$ & -- & $92 / 92$ & -- & $49 / 92$ & -- \\
\hline $\begin{array}{l}\text { Report vermin } \\
\text { (fix my street) }\end{array}$ & yes & $\mathrm{n} / \mathrm{a}$ & 56 & -- & 73 & -- & $72^{3}$ & -- \\
\hline Report theft & yes & $\mathrm{n} / \mathrm{a}$ & 41 & -- & 84 & -- & 84 & -- \\
\hline
\end{tabular}


While Denmark has monitored the degree of digitization under the previous eGovernment strategy, this was discontinued in January 2017 as the mandatory online self-service initiative was concluded. The final report shows that the collective degree of digitization was $87 \%$ (based on approx. 11.5 million transaction in the period). For central government services, the result was $91 \%$ (of 5.8 million service requests), for local government it was $80 \%$ (of 3.9 million service requests), and for UdbetalingDenmark service areas, $88 \%$ of volume (1.7 million service requests) were online by end of 2015 (DIGST - Digitaliseringsstyrlesen 2017). For Japan, data availability is limited. While data may be collected by individual authorities, this is not coordinated, is rarely comparable (due to different methodologies), and is not collected centrally. Even data on the high profile MyNumber in difficult to come by. This lack of data also makes it hard for the ITSH and ITSC to monitor developments and progress, as confirmed by interviews with both government officials, the coordinating body, and supported by academics. (Interview 1 Japan 2016, Interview 3 Japan 2016, Interview 4 Japan 2016, Interview 6 Japan 2016).

When seeking alternative generic data for the proportion of citizens use of online banking (eBanking), online purchases (eCommerce), and their level of interaction with public authorities online, this data was mainly identifiable for Denmark, as illustrated in Table 10. Interviews with both government officials (Interview 2 Japan 2016, Interview 3 Japan 2016, Interview 4 Japan 2016, Interview 5 Japan 2016) and academics (Interview 1 Japan 2016) confirm that data is not systematically collected in Japan by either the ITSH, other authorities, or the statistical services.

Table 10: Citizens use of eBanking, eCommerce and interaction with public authorities online 2000-2016 (at least once per year), selected years (Eurostat 2017)

\begin{tabular}{|l|l|l|l|l|l|l|}
\hline & $\mathbf{2 0 1 0}$ & & $\mathbf{2 0 1 5}$ & & $\mathbf{2 0 1 6}$ & \\
\hline & Denmark & Japan & Denmark & Japan & Denmark & Japan \\
\hline Online banking & $71 \%$ & -- & $85 \%$ & $1 \%^{2}$ & $88 \%$ & -- \\
\hline Online commerce & $68 \%$ & $49 \%^{3}$ & $79 \%$ & $52 \%^{7}$ & $82 \%$ & -- \\
\hline $\begin{array}{l}\text { Interacted with government } \\
\text { online }\end{array}$ & $78 \%$ & $13 \%$ & $88 \%$ & -- & $88 \%$ & -- \\
\hline $\begin{array}{l}\text { Obtained info. from gov. website } \\
\text { Submitted a complete form }\end{array}$ & $76 \%$ & -- & $86 \%$ & -- & $85 \%$ & -- \\
\hline
\end{tabular}

${ }^{2}$ Figure varies from $13 \%$ to $16 \%$ depending on source. Mode of contact defined as mobile phone Kawamoto, S. (2015). Internet banking slow to take root in nation where branches offer friendly face time. The Japan Times. Tokyo, The Japan Times.

${ }^{3}$ Online commerce figures based on a different collection methodology and from 2010 and 2014 OECD. (2016). "ICT access and use by individuals." OECD.Stat Retrieved 29 June 2016, 2016, from http://stats.oecd.org/. 


\section{(eService)}

While both Denmark and Japan are included in the international eGovernment indexes of the United Nations and Waseda University, neither index addresses the actual use of the online services that are offered (Obi 2016, UNDESA - United Nations Department of Economic and Social Affairs 2016). The biannual UNDESA eGovernment Readiness Index covers both human capacity (i.e. HCI - Human Capacities Index), technology and infrastructure availability (i.e. TII - Technical Infrastructure Index), and the availability of specific types of online content and transaction (i.e. OSI - Online Service Index). The rank of both Denmark and Japan are consistently in the global Top 20, as illustrated in Table 11. The difference seems to be explained mainly by the human capacity score, which is consistently higher in Denmark for the 2010-2016 period. By comparison, Japan has been catching up with Denmark and slightly outperforming Denmark in the 2016 edition. This is more or less consistent with the findings in section 5.1. and the data in Tables 7 and 8. That Japan is outperforming Denmark in the online service index is surprising in relation to the online service use data in Tables 9 and 10, and the limited take-up of the high-profiled MyNumber eID/digital signature in Japan (JiJI 2017). Three reasons may explain the Japanese OSI score: first, the UNDESA OSI is supply-orientated and thus does not measure actual use of public or private sector services; second, the OSI included open data availability, an area in which Denmark has not had a particular focus on, while Japan has had an open data strategy since 2012 (ITSH - IT Strategic Headquarter 2012); third, the OSI only addresses a select number of central government website, whereas local government is responsible for $+70 \%$ of service delivery in both Denmark and Japan.

Table 11: UNDESA eGovernment Readiness Index, 2010-2016 (UNDESA - United Nations Department of Economic and Social Affairs 2010, 2012, 2014, 2016)

\begin{tabular}{|l|l|l|l|l|l|l|l|l|}
\hline & \multicolumn{2}{l}{2010} & \multicolumn{2}{l}{2012} & 2014 & 2016 \\
\hline & Denmark & Japan & Denmark & Japan & Denmark & Japan & Denmark & Japan \\
\hline Rank & 7 & 17 & 4 & 18 & 16 & 6 & 9 & 11 \\
\hline $\begin{array}{l}\text { EGDI - eGov. } \\
\text { Devl. Index }\end{array}$ & 0.7872 & 0.7152 & 0.8889 & 0.8019 & 0.8162 & 0.8874 & 0.8510 & 0.8440 \\
\hline $\begin{array}{l}\text { HCI - Human } \\
\text { Capacity Index }\end{array}$ & 0.9933 & 0.9496 & 0.9489 & 0.8969 & 0.9132 & 0.8621 & 0.9530 & 0.8278 \\
\hline $\begin{array}{l}\text { TII - Technical } \\
\text { Infra. Index }\end{array}$ & 0.6988 & 0.5242 & 0.8615 & 0.6460 & 0.8740 & 0.8553 & 0.8247 & 0.8277 \\
\hline $\begin{array}{l}\text { OSI - Online } \\
\text { Service Index }\end{array}$ & 0.6730 & 0.6730 & 0.8562 & 0.8627 & 0.6614 & 0.9449 & 0.7745 & 0.8768 \\
\hline
\end{tabular}

The Waseda Index covers network preparedness, eService and national portal availability, and some management and governance issues. Based on the data in Table 12, Denmark generally outranks Japan in the Waseda Index. For 2016, Denmark outperforms Japan in all but Government 
$\mathrm{CIO}$ and eGovernment promotion subcategories (similarly in 2012 and 2015). This is particularly interesting as the eGovernance model in Denmark seems to have achieved better outcomes in relation to infrastructure roll-out and online service use, and similar results for mobile and broadband subscriptions. Explanations for this include: first, the supply-orientated methodology of the Waseda Index, which does not consider take-up of eService and benefit realization (remember that e.g. the 2016 take-up of the Japanese MyNumber was an estimated 9.2\% compared to $92 \%$ for the Danish NemID equvilent); second, the Japanese eGovernance model is anchored in the Cabinet Office, while the Danish is a specialized agency within the Ministry of Finance; third, the Danish model is more complex in nature as it covers all levels of government, while Japan's focuses on central government ICT use.

Figure 12: Waseda Index for eGovernment, 2012-2016 (Obi 2012, 2015, 2016)

\begin{tabular}{|c|c|c|c|c|c|c|}
\hline & 2012 & & 2015 & & 2016 & \\
\hline & Denmark & Japan & Denmark & Japan & Denmark & Japan \\
\hline $\begin{array}{l}\text { Overall eGovernment } \\
\text { ranking }\end{array}$ & $5(86.5)$ & $8(81.5)$ & $3(91.25)$ & $6(87.77)$ & $3(88.8)$ & $5(83.2)$ \\
\hline Network preparedness & 3 & $<10$ & 1 & $<10$ & $1(7.9)$ & $7(7.4)$ \\
\hline $\begin{array}{l}\text { eServices/interface } \\
\text { (selected services)\# }\end{array}$ & 4 & 9 & 1 & 9 & $2(11.2)$ & $9(7.8)$ \\
\hline $\begin{array}{l}\text { Portal (i.e. national one- } \\
\text { stop-shop) }\end{array}$ & 7 & 7 & 2 & $<10$ & $2(7.3)$ & $<10(4.7)$ \\
\hline Management optimization & 8 & 10 & 6 & 4 & $1(11.8)$ & $4(11.5)$ \\
\hline $\begin{array}{l}\text { Government } \mathrm{CIO} \text { (i.e. } \\
\text { governance aspect) }\end{array}$ & $<10$ & 5 & 5 & 8 & $5(8.4)$ & $2(9.1)$ \\
\hline $\begin{array}{l}\text { eGovernment promotion } \\
\text { (i.e. strategy) }\end{array}$ & 9 & 4 & 8 & 5 & $4(8.3)$ & $2(9.3)$ \\
\hline
\end{tabular}

* Score for criteria and sub-criteria are not available online.

\#Title of criteria changed from 2012 "required interphase/application" to "online service" in 2015.

\section{Comparative Analysis and Conclusions}

Focusing on electronic service provision (eServices) and eGovernment achievements in Japan and Denmark, Meyerhoff Nielsen and Igari (Meyerhoff Nielsen and Igari 2012) identified governance and intergovernmental cooperation as key factors for a successful eService supply and citizen takeup. Japan, generally, had a better infrastructure than Denmark, but lacked unique identifiers for individuals, businesses, property, and national one-stop-shops for services. Denmark's unique identifiers and digital signature systems, such as the population register (the CPR registry) and 
business register (the CVR and BBR registries), enabled the creation of user-centric web services on thematic portals, for example, Borger.dk, Virk.dk or Sundhed.dk (national portals for citizens, businesses, and health, respectively) (Meyerhoff Nielsen and Igari 2012). The comparatively higher level of strategic governance and intergovernmental cooperation in Denmark suggests their importance for the successful roll-out and subsequent citizen use of eServices.

While Japan continues to have a more complex institutional framework and approach to governance, intergovernmental cooperation is seemingly also less entrenched in Japan, as illustrated by taxation. In relation to eGovernance, Japan had a relatively stable institutional framework since the early 2000s. Denmark, by comparison, has gone through cycles of evaluation and adjustment with each eGovernment strategy. While stability can be seen as a strength, the continued self-reflection and improvement in Denmark has led to a strong central mandate, which is used only when consensus and cooperation fails. In fact, the relative Danish advantages in relation to national standards, such as interoperability and enterprise architecture first identified by Meyerhoff and Igari in 2012 (Meyerhoff Nielsen and Igari 2012), continues to apply. Similarly, the observed advantage in relation to shared key enablers, common components, reuse of data, common look-and-feel across online government platforms and services, user-centric and userfriendly online services participatory design and testing, has manifested as even bigger weaknesses in Japan, as seen by the slow take-up of the high-profile MyNumber initiative and continued discussion about the introduction of a national interoperability framework.

To compare the two national approaches to eGovernance and inter-governmental cooperation, Tables 13 and 14 enable a comparison of Danish and Japanese approaches to cooperation in relation to the policy (i.e. vision and strategy setting) and operational levels (i.e. implementation). Both Japan's ITSC and ITSH, and Denmark's DIGST, are deemed to have real influence in relation to setting the political agenda regarding ICT use and eServices. This is confirmed by both desk research and interviews with different stakeholders in both countries. Where the two countries differ is in relation to the operational level and the implementation of the national vision and strategy. In Denmark, the PSC for the eGovernment strategy, and DIGST within the MoF, established the holistic political direction, horizontal and vertical leadership, strategies, and coordination required for joint initiatives and cooperation between national, regional and local authorities, therefore giving citizens and businesses a sense of institutions speaking with a "single voice". Similarly, the formalization of steering committees and working groups with the 2016 strategy ensures that conflict resolution, essential coordination between initiatives, re-prioritisation of initiatives, budgets and even coordinated resolution of legal challenges is entrenched in the governance and cooperation model. By comparison, Japan's Government CIO and ITSH have long had a formal annual process for re-evaluation and re-prioritisation of strategic initiatives at central government level - as illustrated by updated policy documents. Japan's Government CIO and ITSH is similarly tasked with coordination, but are not given the mandate to ensure compliance when faced with conflicting interests. 
Table 13: Denmark's eGovernance and coordination model since 2016 (source: author)

\begin{tabular}{|l|l|l|}
\hline & $\begin{array}{l}\text { Co-ordination } \\
\text { of the } \\
\text { implementatio } \\
\text { n of strategy }\end{array}$ & $\begin{array}{l}\text { Wider co- } \\
\text { ordination } \\
\text { of the } \\
\text { developmen } \\
\text { t of } \\
\text { information } \\
\text { society }\end{array}$ \\
\hline Vision & $\begin{array}{l}\text { DIGST and the } \\
\text { PSC }\end{array}$ & $\begin{array}{l}\text { DIGST } \\
\text { facilitated } \\
\text { consultation }\end{array}$ \\
\hline Strategy & $\begin{array}{l}\text { DIGST and the } \\
\text { PSC }\end{array}$ & $\begin{array}{l}\text { DIGST } \\
\text { facilitated } \\
\text { consultation }\end{array}$ \\
\hline $\begin{array}{l}\text { Implementa } \\
\text {-tion of } \\
\text { action plans }\end{array}$ & $\begin{array}{l}\text { DIGST } \\
\text { Programme and } \\
\text { project steering } \\
\text { committees } \\
\text { PSC for } \\
\text { escalation }\end{array}$ & $\begin{array}{l}\text { DIGST } \\
\text { arogramme project } \\
\text { steering } \\
\text { committees }\end{array}$ \\
\hline $\begin{array}{l}\text { Daily } \\
\text { implementa } \\
\text {-tion and } \\
\text { everyday } \\
\text { work }\end{array}$ & $\begin{array}{l}\text { Programme and } \\
\text { project steering } \\
\text { committees } \\
\text { Individual } \\
\text { Ministries and } \\
\text { authorities }\end{array}$ & $\begin{array}{l}\text { Programme } \\
\text { and project } \\
\text { steering } \\
\text { committees }\end{array}$ \\
\hline
\end{tabular}

Table 14: Japan's eGovernance and coordination model since 2003 (source: author)

\begin{tabular}{|c|c|c|}
\hline & $\begin{array}{l}\text { Co-ordination } \\
\text { of the } \\
\text { implementatio } \\
n \text { of strategy }\end{array}$ & $\begin{array}{l}\text { Wider co- } \\
\text { ordination } \\
\text { of the } \\
\text { developmen } \\
t \text { of } \\
\text { information } \\
\text { society }\end{array}$ \\
\hline Vision & ITSH & ITSH, ITSC \\
\hline Strategy & ITSH & $\begin{array}{l}\text { ITSC, } \\
M I C / L B A\end{array}$ \\
\hline $\begin{array}{l}\text { Implementa- } \\
\text { tion of } \\
\text { action plans }\end{array}$ & $\begin{array}{l}\text { ITSH and PMO } \\
\text { units }\end{array}$ & \\
\hline $\begin{array}{l}\text { Daily } \\
\text { implementat } \\
\text {-ion and } \\
\text { everyday } \\
\text { work }\end{array}$ & $\begin{array}{l}\text { ITSH and PMO } \\
\text { units } \\
\text { Individual } \\
\text { Ministries and } \\
\text { responsible } \\
\text { agencies }\end{array}$ & \\
\hline
\end{tabular}

The Danish cross-governmental model revolves around the PSC within DIGST and the Ministry of Finance. The PSC creates horizontal connections across the central government agencies, as well as vertical connections among the central government, regions, and municipalities. Joint initiatives and cooperation between public authorities at all levels of government gives citizens and businesses a sense of the government and institutions speaking with a "single voice". While public-private cooperation and projects do exist (e.g., the digital postbox, eID and eSignature), there could be better civil society and private sector representation - the latter is partially seen in Japan since the establishment of the ITSC in 2002 - in the joint-steering committee to ensure that the public sector cost saving agenda also benefits citizens and businesses (e.g., through administrative burden reduction and user-centric and proactive service delivery). An unfortunate aspect of the current 2016-2020 strategy is the vague formulation of measurable outcomes and KPIs - a change from the previous strategic periods' very ambitious goals.

Although Japan's ITSH is a cross-agency, cross-staffed organization, its political influence, agenda setting role, budget and leadership, are all weak compared to its Danish counterpart. Despite annual priority policy programs supporting the strategic objectives of the eGovernment strategies, there is limited evidence of an actual benefit realization in strategic initiatives - the 
repeated delay of the decision to introduce a unique personal identifier is a key example of this challenge. Japan's 2016-2020 strategy does address the need for a more coordinated approach to governance and intergovernmental cooperation, monitoring of progress, and KPIs, but as seen in section 6, data is only sporadically available and lacks measurable objectives in many ICT related strategy documents (Kantei 2015, ITSH - IT Strategic Headquarter 2016, ITSH - IT Strategic Headquarter 2016).

To analyze the difference between the governance and cooperation models further, Figures 6 and 7 outline the formal and informal structures of importance in Denmark and Japan. In the case of Denmark, no informal networks are indicated. The interviews confirm that they tend to mirror and compliment formal structures, in contrast to Japan.

Figure 6: Organigram of Denmark's eGovernance and coordination model since 2016 (source: author)
Figure 7: Organigram of Japan's eGovernance and coordination model being implemented in 2003 (source: author)
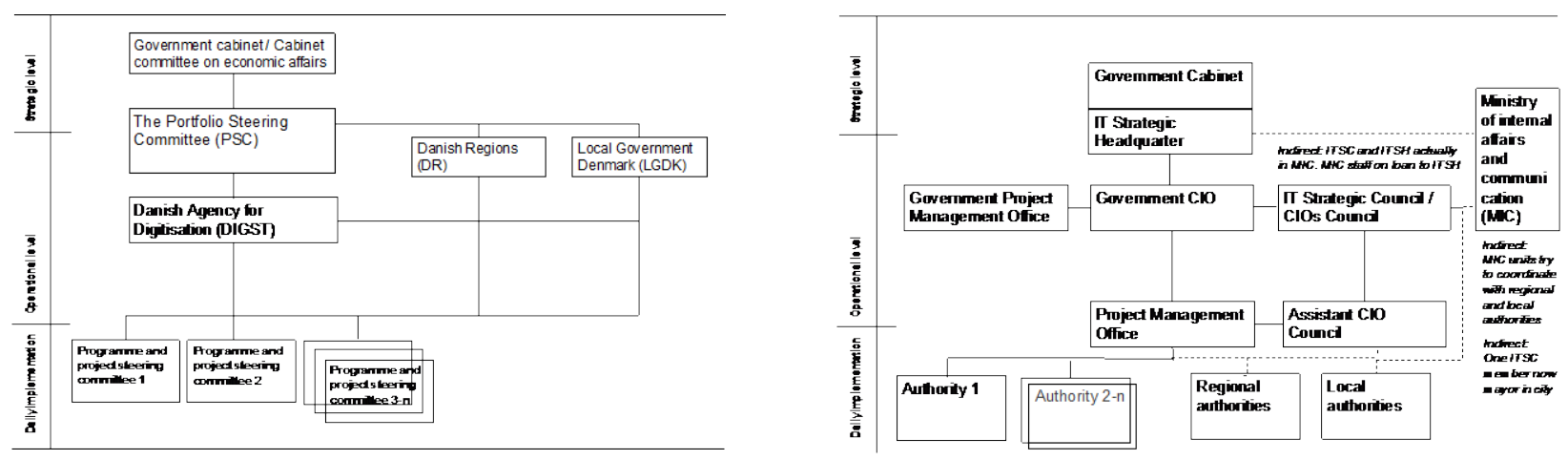

The role of personal contacts and informal networks in Japan comes to light in different ways. While spilt between the mandate in the ITSH, the chairpersonship of the ITSC and Japan's MIC regulatory responsibility is, in theory, a source of potential conflict. In reality, both the ITSH and ITSC are located in MIC buildings and a large number of MIC staff are on loan to the ITSH. Interviews confirm that personal contacts and informal networks ensure coordination between different ITSH, ITSC and MIC interests, as illustrated in Figure 7. Similarly, local government is represented in the ITSC by lucky coincidence; that is, the election of a former MIC and ITSH employee to be Mayor, who has since become a member of the ITSC. Similarly, the LAB coordinates with prefectures and municipalities, but the sporadic availability of eServices at local government level for, e.g. limited take-up of MyNumber, change of address, registration for school, daycare etc., indicates that it is not always successful. The complex structure of public administration in Japan is also seen as a barrier by a number of sources and interviewees.

As observed in 2012, this analysis shows that the Danish approach continues to prove its worth, not only in providing the strategic direction, but also by delivering real and measurable results of digitization. The Japanese model has been more ambitions and successful in infrastructure rollout, open data and piloting new technologies like artificial intelligence, but has yet to deliver similar measurable results in the area of such as interoperability, eIDs and public sector services. While 
initially delayed, Japan is now rolling an eID (i.e. MyNumber); similarly, the volume of online tax submissions is increasing, and the country has a vibrant open data community. The comparatively weak mandate, complex set-up, lack of cross-governmental cooperation, lack of prefecture and municipality representation in Japan seems to continue to limit measurable progress in relation to cross-governmental and citizen-orientated initiatives. The general lack of background and effect indicators for Japan is unfortunate, however, highlights a limited focus on measurable objectives and/or lack of management focus when it comes to the strategic focus on citizen eServices. Unfortunately, the mandate of the new government CIO only allows for the coordination and does not have the power to ensure a systematic approach to monitoring and measurement of the strategies and initiatives, implementation, and KPIs.

\section{Conclusions}

In conclusion, and in relation to Meyerhoff Nielsen and Igari's 2012 findings (Meyerhoff Nielsen and Igari 2012), these still hold. Subsequent analysis of existing academic research, policy documents and websites (Meyerhoff Nielsen 2016), and interviews with actors and stakeholders, have added additional insight to the respective national models for governance and intergovernmental cooperation.

Japan can still learn from the Danish approach in a number of ways. The governance structure and mandate of Japan could be strengthened, and while the current 2016-2020 strategy emphasizes greater coordination, monitoring and measurable outcomes are yet to be proven in practice. Similarly, representatives from regional and local authorities should be included in the ITSC, especially as the current strategy included the regional and local roll-out of successful national initiatives, use of national ID cards, and eIDs. Although the initiatives on standardized formats and processes, shared components and contents, involvement of end-users in developing value adding, personal and user-friendly services based on the eID, and open data initiatives are highlighted by the 2016-2020 strategic period, it remains unclear whether their promise will be realized.

The Danish adjustment introduced with the 2016-2020 strategy is positive in relation to the strengthened mandate of the PSC, the creation of the standing committees on legal and budgetary issues, and a more structured approach to steering committees and working groups on the operational level. In relation to stakeholders involvement, the Japanese involvement of representatives from the private sector and academia should be of inspiration to the Danish coordinating agency. While the private sector and academia representatives in the PSC may not be practical in relation to day-to-day operational decisions, it would be beneficial to draw on their expertise and knowledge - particularly when developing new strategies and initiatives. Valuable private sector and academia contributions could be provided on emerging technologies, such as artificial intelligence and block chain, and concepts, such as Smart cities and Internet of Things, on ways to minimize risk emerging in initiatives - or even act as a form of peer review mechanism during a strategy period. Similarly, more transparency in the consultation process for news strategies and action plans have the potential to further increase local government co-ownership. Also, Denmark could also be inspired by the Japanese approach to piloting new technologies, 
opening data for reuse by civil society and the private sector, with Denmark being the positive example and Japan being relatively less successful as a result of the limited inclusion of regional and local government actors. A relatively weak mandate of the government $\mathrm{CIO}$ to ensure compliance with national strategies is also to blame here

In short, both the Danish and Japanese cases add insight to the role that a strong governance model and high level of intergovernmental cooperation lead to the successful supply and use of online citizen services. In fact, both cases show that a strong governance model lead to (i) supply and (ii) use of online services (i.e. Hypothesis 1), with Denmark being the positive example and Japan being relatively less successful as a result of the limited inclusion of regional and local government actors, together with a relatively weak mandate of the government $\mathrm{CIO}$ to ensure compliance with national strategies. Similarly, the Danish case illustrates that a high level of intergovernmental cooperation lead to (i) supply and (ii) use of online services (i.e. Hypothesis 2), but that the cooperation must be on related supply issues (e.g. availability of internet, eIDs, eServices), the coordinated promotion and monitoring of actual use of supplied eIDs and eServices. By comparison, the limited cooperation between levels of government in Japan have led to a more fragmented approach to the development of a national eID solution and eServices at different levels of government. The two cases both support a strong coordinated link between national vision, strategy, action plan and initiatives leads to lead to (i) supply (ii) use of online services (i.e. Hypothesis 3). While the Danish case illustrated the benefit in relation to the supply and citizens actual use of eServices, the Japanese case illustrated in relation to the achievements of ultra-fast broadband. The lack of a coordinated vision and strategic focus, e.g. eID take-up and cross-governmental promotion of existing online service offer, have led to a diametrically different outcome in Japan.

In conclusion, the two cases provide insight on the role that governance and intergovernmental cooperation plans in relation to the successful provision and use of online citizen services in two countries with different organizational set-ups and traditions. In order to explore if the working hypothesis will hold in other socio-economic and organizational contexts, the author will attempt to answer the same question in relation to: Georgia, a low-income nation state with regional differences and limited local government capacities but increasing service delivery; Estonia, a small, middle-income nation state with a centralized government and limited service delivery and capacities at local level, and; the Faroe Islands, a high-income, centralized, micro-dependency with large autonomy given to local authorities, including for public service delivery.

\section{References}

Alhomod, S. M. and M. M. Shafi (2012). "Best Practices in E government: A review of Some Innovative Models Proposed in Different Countries." International Journal of Electrical \& Computer Sciences 12(2): $1-6$.

Andersen, K. V. and H. Z. Henriksen (2006). "E-government maturity models: Extension of the Layne and Lee model." Government information quarterly 23(2): 236-248.

Bannister, F. (2001). "Dismantling the silos: extracting new value from IT investments in public administration." Information Systems Journal 11(1): 65-84. 
Bannister, F. (2007). "The curse of the benchmark: an assessment of the validity and value of e-government comparisons." International Review of Administrative Sciences 73(2): 171-188.

Bannister, F. and R. Connolly (2011). Transformation and Public Sector Values. tGov 11. London, Brunel University. 11.

Benbasat, I., D. K. Goldstein and M. Mead (1987). "The case research strategy in studies of information systems." MIS quarterly 11(3): 369-386.

Brown, A. E. and G. G. Grant (2005). "Framing the frameworks: A review of IT governance research." Communications of the Association for Information Systems 15(1): 38.

Brown, C. V. and S. L. Magill (1994). "Alignment of the IS functions with the enterprise: toward a model of antecedents." MIS quarterly 18(4): 371-403.

Bryman, A. and E. Bell (2015). Business research methods. New York, Oxford University Press, USA.

Bureau, L.-L. A. (2017). "Promotion of regional decentralisation." Retrieved 25 August, 2017, from http://www.soumu.go.jp/english/lab/index.html.

Chen, J. Y., Y.; Mingins, C. (2011). "A Three-Dimensional Model for E-Government Development with Cases in China's Regional E-Government Practice and Experience." ICMeCG, 2011 Fifth International Conference on Management of e-Commerce and e-Government: 113-120.

Christine Leitner, J.-M. E., François Heinderyckx, Klaus Lenk, Morten Meyerhoff Nielsen, Roland Traunmüller (2003). eGovernment in Europe: The State of Affairs: 66.

CIA - Central Intelligence Agency. (2017). "The World Factbook." Retrieved 25 August, 2017, from https:/ / www.cia.gov/library/publications/the-world-factbook/rankorder/2119rank.html.

Collier, D. and J. Mahoney (1996). "Insights and pitfalls: Selection bias in qualitative research." World Politics 49(01): 56-91.

Cordella, A. and C. M. Bonina (2012). "A public value perspective for ICT enabled public sector reforms: A theoretical reflection." Government information quarterly 29(4): 512-520.

de Bri, F. and F. Bannister (2010). "Whole-of-government: The continuing problem of eliminating silos." Proceedings of the 10th European Conference on eGovernment, National Centre for Taxation Studies and University of Limerick, Ireland: 122-133.

de Bri, F. and F. Bannister (2015). E-Government Stage Models: A Contextual Critique. System Sciences (HICSS), 2015 48th Hawaii International Conference on, IEEE.

Devos, G., M. Buelens and D. Bouckenooghe (2007). "Contribution of content, context, and process to understanding openness to organizational change: Two experimental simulation studies." The Journal of social psychology 147(6): 607-630.

Dias, G. P. and H. Gomes (2014). Evolution of local e-government maturity in Portugal. Information Systems and Technologies (CISTI), 2014 9th Iberian Conference on, IEEE.

DIGST - Digitaliseringsstyrelsen (2011). The digital path to future welfare: Joint national eGovernment strategy 2011-2015. Copenhagen, DIGST -Digitaliseringsstyrelsen. 
DIGST - Digitaliseringsstyrlesen. (2016). "Digitaliseringsstyrelsen." Retrieved 25 March 2016, 2016, from http://www.digst.dk/

DIGST - Digitaliseringsstyrlesen (2016). Et stærkere og mere trygt digitalt samfund: Den fællesoffentlige digitaliseringsstrategi 2016-2020. Copenhagen, DIGST - Digitaliseringsstyrelsen.

DIGST - Digitaliseringsstyrlesen (2016). Governance. Copenhagen, DIGST - Digitaliseringsstyrelsen.

DIGST - Digitaliseringsstyrlesen. (2017). "Det digitale scorecard." Retrieved 29 March 2016, 2016, from http://www.scorecard.digst.dk/

https:// www.digst.dk/Digital-inklusion/Selvbetjeningsloesninger/Selvbetjeningsgrad.

EC - European Commission (2012). Public Services Online 'Digital by Default or by De-tour?' Assessing User Centric eGovernment performance in Euorpe - eGovernment Benchmark 2012. Brussels, European Commission.

EC - European Commission (2014). Delivering the European Advantage? 'How European governments can and should benefit from innovative public services'. Brussels, European Commission DG Communications Networks, Content \& Technology.

Eurostat. (2017). "Information society household survey." Retrieved 25 August 2017, 2017, from http://ec.europa.eu/eurostat/web/information-society/data/database.

Heeks, R. (2005). Implementing and managing eGovernment: an international text. New York, Sage.

Heeks, R. (2015). A better eGovernment maturity model. iGovernment Briefing. Manchester, University of Manchester.

Heeks, R. and S. Bailur (2007). "Analyzing e-government research: Perspectives, philosophies, theories, methods, and practice." Government Information Quarterly 24(2): 243-265.

Hiramoto, K. (2013). e-Government and Open Government Data in Japan. Tokyo, Ministry of Economy, Trade and Industry.

Huijboom, N. v. d. B., Thijs; Frissen, Valarie; Kool, Linda; Kotterink, Bas; Meyerhoff Nielsen, Morten; Millard, Jeremy (2009). Public services 2.0: Key areas in the public sector impact of social computing: 134.

Igari, N. (2014). "How to successfully promote ICT usage: A comparative analysis of Denmark and Japan." Telematics and Informatics 31(1): 115-125.

Interview 1 Denmark (2017). Interview with representative(s) from national portal team and central government. M. Meyerhoff Nielsen. Copenhagen.

Interview 1 Japan (2016). Interview with representative(s) from academia. M. Meyerhoff Nielsen.

Interview 2 Denmark (2017). Interview with representative(s) from private sector. M. Meyerhoff Nielsen.

Interview 2 Japan (2016). Interview with representative(s) from coordinating agency. M. Meyerhoff Nielsen.

Interview 3 Denmark (2017). Interview with representative(s) from local government. M. Meyerhoff Nielsen. 
Interview 3 Japan (2016). Interview with representative(s) from coordinating agency and central government. M. Meyerhoff Nielsen.

Interview 4 Denmark (2017). Interview with representative(s) from cordinating agency, portal team, central government. M. Meyerhoff Nielsen.

Interview 4 Japan (2016). Interview with representative(s) from national portal team and central government. M. Meyerhoff Nielsen.

Interview 5 Denmark (2017). Interview with representative(s) from local government. M. M. Nielsen.

Interview 5 Japan (2016). Interview with representative(s) from central government, regional government, local government. M. Meyerhoff Nielsen. Tokyo.

Interview 6 Denmark (2017). Interview with representative(s) from coordinating agency. M. Meyerhoff Nielsen.

Interview 6 Japan (2016). Interview with representative(s) from academia. M. Meyerhoff Nielsen.

Interview 7 Denmark (2017). Interview with representative(s) from local government. M. Meyerhoff Nielsen.

Interview 8 Denmark (2017). Interview with representative(s) from academia. M. Meyerhoff Nielsen.

Interview 9 Denmark (2017). Interview with representative(s) from local government. M. Meyerhoff Nielsen.

Interview 10 Denmark (2017). Interview with representative(s) from central government. M. Meyerhoff Nielsen.

Iribarren, M., G. Concha, G. Valdes, M. Solar, M. T. Villarroel, P. Gutiérrez and Á. Vásquez (2008). Capability maturity framework for eGovernment: A multi-dimensional model and assessing tool. Electronic Government, Springer: 136-147.

ITSH - IT Strategic Headquarter (2010). The New Strategy in Information and Communications Technology (IT): Roadmaps. ITSH - IT Strategic Headquarter. Tokyo, ITSH, IT Strategic Headquarter.

ITSH - IT Strategic Headquarter (2012). Open Government Data Strategy. I. S. H. ITSH. Tokyo, ITSH - IT Strategic Headquarter,.

ITSH - IT Strategic Headquarter (2016). Declaration to be the World's Most Advanced IT Nation. ITSH - IT Strategic Headquarter. Tokyo.

ITSH - IT Strategic Headquarter. (2016). "IT Policy: Major Steps and Decisions Taken." Retrieved 25 March 2016, 2016, from http://japan.kantei.go.jp/policy/it/index_e.html.

ITSH - IT Strategic Headquarter. (2016). "IT 総合戦略本部) eガバメント閣僚会議 / IT Strategy Headquarters, eGovernment ministerial meeting." Retrieved 2 October 2016, 2016, from http://www.kantei.go.jp/jp/singi/it2/egov/index.html.

ITSH - IT Strategic Headquarter (2016). Members of the Strategic Headquarters for the Promotion of an Advanced Information and Telecommunications Network Society. Tokyo, ITSH - IT Strategic Headquarter,. 
ITU - Internet Telecommunications Union. (2014). "Worlds Telecommunication / ICT Indicators Database." from http://www.itu.int/en/ITU-D/Statistics/Pages/publications/wtid.aspx.

ITU - Internet Telecommunications Union. (2017). "Worlds Telecommunication / ICT Indicators Database." Retrieved 25 August, 2017, from http://www.itu.int/en/ITU-

D/Statistics/Pages/publications/wtid.aspx.

Jain, P. (2002). "The catch-up state: E-government in Japan." Japanese Studies 22(3): 237-255.

Janssen, M., Y. Charalabidis and A. Zuiderwijk (2012). "Benefits, adoption barriers and myths of open data and open government." Information Systems Management 29(4): 258-268.

JiJI (2017). A year into new system, Japan's My Number ID cards are not catching on. The Japan Times. Tokyo, The Japan Times.

Kantei (2015). e ガバメント閣僚会議 ワーキンググループ(国・地方 I T化・B P R 推進チーム) 23 April 2015 / eGovernment Council of Ministers working group (national and local IT in · BPR Promotion Team) Minutes 23 April 2015. P. O. Kantei. Tokyo.

Kantei (2016). マイナンバーカードの発行および利活用の進捗状況等について. P. O. Kantei. Tokyo.

Kantei (2016). 国・地方 I T化・B P R 推進チーム)（第 4 回）議事要旨, 28 April 2016 / National and local IT in · BPR Promotion Team) (4th) Proceedings summary, 28 April 2016. P. O. Kantei. Tokyo.

Kawamoto, S. (2015). Internet banking slow to take root in nation where branches offer friendly face time. The Japan Times. Tokyo, The Japan Times.

Klievink, B. and M. Janssen (2009). "Realizing joined-up government-Dynamic capabilities and stage models for transformation." Government Information Quarterly 26(2): 275-284.

Klischewski, R. and H. J. Scholl (2008). "Information quality as capstone in negotiating e-government integration, interoperation and information sharing." Electronic Government, an International Journal 5(2): 203-225.

Krimmer, R. (2012). "The evolution of e-voting: why voting technology is used and how it affects democracy." Tallinn University of Technology Doctoral Theses Series I: Social Sciences(19).

Lee, G. and Y. H. Kwak (2012). "An open government maturity model for social media-based public engagement." Government Information Quarterly 29(4): 492-503.

Lee, J. (2010). "10 year retrospect on stage models of e-Government: A qualitative meta-synthesis." Government Information Quarterly 27(3): 220-230.

Lips, M. (2012). "E-government is dead: Long live public administration 2.0." Information Polity 17(3): 239250.

Meyerhoff, M. and A. Kelly (2011). "Scandinavia 2.0: Efficiency, cooperation and innovations to alleviate the Economic Crisis." European Journal of ePractice 11: 19-38.

Meyerhoff Nielsen, M. (2011). "Danish eGovernment Success Factors: Strategies and Good Practice Examples." Global Strategy and Practice of E-Governance: Examples from Around the World: Examples from Around the World: 231. 
Meyerhoff Nielsen, M. (2014). "Identifying eGovernment success factors: An analysis of selected national governance models and their experiences in digitising service delivery." Proceedings of the 2014 Conference on Electronic Governance and Open Society: Challenges in Eurasia: 19-25.

Meyerhoff Nielsen, M. (2015). "Supply and use of citizen eServices: An analysis of selected national experiences in relation to existing governance and cooperation modesl." NISPAcee Journal of Public Administration and Policy.

Meyerhoff Nielsen, M. (2016). "eGovernment and Governance: The Danish-Japanese timelines and models compared." CeDEM Asia 2012: 53-66.

Meyerhoff Nielsen, M. (2016). Governance and Online Service Delivery: The Danish Case. 15th IFIP Electronic Government (EGOV) and 8th Electronic Participation (ePart) Conference 2016, Guimarães, IOS Press.

Meyerhoff Nielsen, M. (2016). Governance and online service delivery: The Danish case. Electronic Government and Electronic Participation, Guimaraes, IOS Press.

Meyerhoff Nielsen, M. (2016). The Role of Governance, Cooperation, and eService Use in Current eGovernment Stage Models. Hawaii.

Meyerhoff Nielsen, M. (2016). "The use, the service and the Danish approach to online user-friendliness." Pro Publico Bono-Public Administration Forthcoming.

Meyerhoff Nielsen, M. (2017). Governance failure in light of Government 3.0: Foundations for building next generation eGovernment maturity models. Government 3.0 - Next Generation Government Technology Infrastructure and Services - Opportunities, Enabling Technologies, Challenges and Roadmaps. A. M. Ojo, Jeremy, PAIT - Public Administration and Information Technology,.

Meyerhoff Nielsen, M. and N. Igari (2012). "Speaking Danish in Japan." CeDEM 12 Conference for EDemocracy and Open Government 3-4 May 2012 Danube-University Krems, Austria: 137.

Meyerhoff Nielsen, M. Y., Mika (2014). "An analysis of the Danish approach to eGovernment benefit realisation." Internet Technologies and Society 2014 Conference Proceedings: 47-58.

MIC - Ministry of Internal Affairs and Communications. (2017). "Japan's e-Government Initiatives." Retrieved 25 August 2017, 2017, from https://www.e-gov.go.jp/en/e-government.htmlE.

MIC, M. o. I. A. a. C. (2012). State of Affairs of Use of the Internet for Administrative Procedures. Tokyo, Ministry of Internal Affairs and Communication.

Millard, J., E. Normman, M. Holm-Pedersen and M. Meyerhoff Nielsen (2008). Social computing: Trends in Public Services and Policies, JRC-IPTS.

Millard, J. C., Luca; Galasso, Giovanna; Riedl, Reinhard; Neuroni, Alessia C. ; Walser, Konrad; Sami Hamida, Andreas; Huijboom, Noor; Meyerhoff Nielsen, Morten; Leitner, Christine; and R. S. Fehlmann (2007). European eGovernment 2005-2007: Taking stock of good practice and progress towards implementation of the i2010 eGovernment Action Plan: 80.

NIA - National Tax Agency Japan (2015). Annual report 2015. Tokyo, NIA - National Tax Agency Japan,. 
Obi, T. (2012). WASEDA - IAC International e-Government Index. Tokyo, Waseda University and IAC International Agency of CIO.

Obi, T. (2014). WASEDA - IAC International e-Government Index. Tokyo, Waseda University and IAC International Agency of CIO.

Obi, T. (2015). WASEDA - IAC International e-Government Index. Tokyo, Waseda University and IAC International Agency of CIO.

Obi, T. (2016). WASEDA - IAC International e-Government Index. G. S. o. A.-P. S. Toshio Obi Laboratory. Tokyo, Waseda University.

OECD (2011). OECD Public Governance Reviews: Estonia - Towards a Single Government Approach. Paris, OECD.

OECD (2014). Recommendation of the Council on Digital Government Strategies 15 July 2014 - C(2014)88. Paris, OECD.

OECD (2015). OECD Public Governance Reviews: Estonia - Fostering Strategic Capacity across Governments and Digital Services across Borders. Paris, OECD.

OECD. (2016). "ICT access and use by individuals." OECD.Stat Retrieved 29 June 2016, 2016, from http://stats.oecd.org/.

Poeppelbuss, J., B. Niehaves, A. Simons and J. Becker (2011). "Maturity models in information systems research: literature search and analysis." Communications of the Association for Information Systems 29(27): 505-532.

Pollitt, C. and G. Bouckaert (2011). Public Management Reform: A comparative analysis-new public management, governance, and the Neo-Weberian state. Oxford, Oxford University Press.

Rohlfing, I. (2012). Case Studies and Causal Inference: an integrative framework, Palgrave Macmillan.

Ross, J. W., P. Weill and D. Robertson (2006). Enterprise architecture as strategy: Creating a foundation for business execution, Harvard Business Press.

Traunmüller, R. and M. A. Wimmer (2003). E-government at a decisive moment: sketching a roadmap to excellence. Electronic Government, Springer: 1-14.

UNDESA - United Nations Department of Economic and Social Affairs (2008). E-Government Survey 2008: From e-government to connected government. New York, United Nations.

UNDESA - United Nations Department of Economic and Social Affairs (2010). E-Government Survey 2010: Leveraging e-government at a time of financial and economic crisis. New York, United Nations.

UNDESA - United Nations Department of Economic and Social Affairs (2012). E-Government Survey 2012: E-Government for the people. New York, United Nations.

UNDESA - United Nations Department of Economic and Social Affairs (2014). E-Government Survey 2014: E-Government for the future we want. New York, United Nations.

UNDESA - United Nations Department of Economic and Social Affairs (2016). E-Government Readiness Survey Database. New York, United Nations. 
UNDESA - United Nations Department of Economic and Social Affairs (2016). E-Government Survey 2016: E-Government in Support of Sustainable Development. New York, United Nations.

Van den Broek, T. F., Valerie; Huijboom, Noor; Punie, Yves (2010). "The impact of social computing on public services: A ational for Government 2.0." European Journal of ePractice(9): 4-19.

Yin, R. K. (2013). Case study research: Design and methods, Sage publications.

\section{About the Author}

Morten Meyerhoff Nielsen

Morten is an eGovernment and eVoting researcher at the Tallinn University of Technology, Ragnar Nurkse School of Innovation and Governance (www.ttu.ee/ nurkse), in Estonia. He is an independent eGovernment consultant and currently an academic fellow at the United Nations University Operating Unit on PolicyDriven Electronic Governance (UNU-EGOV, https:// egov.unu. edu), working on ICT-enabled administrative burden reduction and public service delivery. He is the author and co-author of various publications, a member of various conference committees, and reviewer for several eGovernment journals. He regularly teaches on eGovernment and social media use (www.msm.nl, www.ttu.ee, www.eipa.eu). Past employment includes the Danish Agency for Digitisation (www. digst.dk), National IT- and Telecom Agency, Borgerkommunikationskontoret/borger.dk (www.itst.dk); Danish Technological Institute, Policy and Business Analysis (www.dti.dk); European Institute of Public Administration (www. eipa.eu); Centre for the Development of Enterprise (www.cde.eu); European Commission, DG DEVL (www. europa.eu/pol/dev/ index_en.htm); and University of KwaZulu-Natal (www.ukzn.ac.za). 